\title{
Impact of pH on the Treatment of Artificial Textile Wastewater Containing Azo Dyes Using Pond Systems
}

\author{
Dina A. Yaseen ${ }^{1} \cdot$ Miklas Scholz $^{1,2,3}$ D \\ Received: 9 October 2018 / Revised: 28 February 2019 / Accepted: 15 March 2019 / Published online: 22 March 2019 \\ (c) The Author(s) 2019
}

\begin{abstract}
Two controlled experiments were operated to evaluate the impact of $\mathrm{pH}$ on the treatment efficiency of azo dyes within artificial textile wastewater using ponds as a polishing step. The objectives were to assess the (1) inflow water quality; (2) the presence of Lemna minor and the algae Oedogonium spp. on the dye removal and the outflow water quality; and (3) suitability of applying artificial textile wastewater and the impact of this wastewater and the dye on plants. Findings indicate that the shallow ponds planted with $L$. minor and/or algae treated the dye Basic Red 46 (BR46) significantly $(p<0.05)$ higher than the control ponds without any significant $(p>0.05)$ impact of $\mathrm{pH}$. The potential of $L$. minor and algae for removal of BR46 was $31 \%$ and $25 \%$, respectively. The removal of BR 46 was around $89 \%$ for ponds planted with $L$. minor and algae, $58 \%$ for algae ponds and $33 \%$ for control ponds. Wetlands with $L$. minor are successful and economic in the complete degradation of BR46 at concentrations of $10 \mathrm{mg} \mathrm{L}^{-1}$ for any $\mathrm{pH}$ value between 6 and 9. The removal of ammonium-nitrogen $\left(\mathrm{NH}_{4}-\mathrm{N}\right)$, nitrate-nitrogen $\left(\mathrm{NO}_{3}-\mathrm{N}\right)$ and ortho-phosphate-phosphorus $\left(\mathrm{PO}_{4}-\mathrm{P}\right)$ was higher in planted than in unplanted ponds. The mean outflow values of chemical oxygen demand, $\mathrm{NH}_{4}-\mathrm{N}, \mathrm{NO}_{3}-\mathrm{N}$, suspended solids and total dissolved solids were within the limits for safe discharge. The artificial wastewater constituents after dilution (1 part of artificial wastewater to 24 parts of raw water) were suitable to use within the treatment system containing L. minor.
\end{abstract}

\section{Article Highlights}

- Planted ponds treat Basic Red 46 significantly better than other dyes and controls.

- No significant impact for systems at pH values of 6 and 9 regarding dye removal.

- Chemical oxygen demand and suspended/dissolved solids outflows were acceptable.

- Ammonium-nitrogen and nitrate-nitrogen outflows were below discharge thresholds.

- Diluted artificial wastewater and the presence dyes inhibited Lemna minor growth.

Keywords Algae $\cdot$ Aromatic amine $\cdot$ Colour removal $\cdot$ Nutrient $\cdot$ Shallow treatment wetland $\cdot$ Sustainable industrial wastewater treatment

Electronic supplementary material The online version of this article (https://doi.org/10.1007/s41742-019-00180-1) contains supplementary material, which is available to authorized users.

Miklas Scholz

miklas.scholz@tvrl.lth.se

1 Civil Engineering Research Group, School of Computing, Science and Engineering, The University of Salford, Newton Building, Greater Manchester M5 4WT, UK

2 Division of Water Resources Engineering, Department of Building and Environmental Technology, Faculty of Engineering, Lund University, P.O. Box 118, 22100 Lund, Sweden

3 Department of Civil Engineering Science, School of Civil Engineering and the Built Environment, University of Johannesburg, Kingsway Campus, P.O. Box 524, Aukland Park, Johannesburg 2006, South Africa 


\section{Introduction}

\section{Background}

This section provides an overview of previous related work and puts this research study into a broader context. The growth of the textile industry worldwide has led to increase in discharge of contaminated water to the environment (Saratale et al. 2011), especially in developing countries, which discharge textile effluents directly to the receiving watercourses (Chandanshive et al. 2016). This direct discharge of textile effluent to a receiving watercourse leads to serious environmental pollution as it contains high concentrations of various difficult-to-degrade contaminants such as dyes, organic matter and aromatic compounds. Azo dyes, which are widely used in the textile industry, inhibit the aquatic life in receiving watercourses, contaminating the water surface vicinity, groundwater and the soil layer properties (Yaseen and Scholz 2016). Furthermore, the intermediate products such as aromatic amines, which occur after azo dye decolourisation, have toxic, mutagenic and carcinogenic effects on life forms (Ong et al. 2010; Yaseen and Scholz 2017a). Therefore, it has become necessary to solve the problems associated with textile industries by treating their effluents using economic and effective strategies to protect receiving ecosystems and enable subsequent recycling of the treated effluents for irrigation purposes or reuse within the textile factory processes (Chandran 2016). Shallow ponds with free-floating plants are recommended as ecosystems, because they require low costs for construction and maintenance, especially when the land value is low, and are effective and sustainable (Yaseen and Scholz 2016). These artificial ponds have proven to be efficient to treat diverse wastewaters. However, pond applications for treating real or simulated textile effluents contaminated with dyes are still limited, and further investigations in this area are required. In addition, authors confirmed the positive impact of optimised $\mathrm{pH}$ regarding textile dye removal using many treatment technologies. However, this parameter required more attention concerning the purification using pond technology, especially the effect of the inflow $\mathrm{pH}$ concerning the long-term system operations.

\section{Rational and Novelty}

Although the $\mathrm{pH}$ has a noticeable impact on dye molecules (Movafeghi et al. 2013), there is no evidence in the literature for studies assessing the long-term effect of $\mathrm{pH}$ concerning pond system performance in terms of dye and other contaminant removal. In addition, no long-term study has been found in the literature on the treatment of synthetic wastewater containing azo dyes mixed with chemicals simulating effluents from textile mills using pond systems vegetated with free-floating plants under hydroponic conditions. Although shallow pond systems have been operated for the treatment of dyes mixed with synthetic wastewater for around 10 months under controlled conditions (Yaseen and Scholz 2016) and for more than 1 year under semi-natural conditions (Yaseen and Scholz 2017b), the researchers used low dye and nutrient concentrations to simulate artificial wastewater using plant fertiliser, which does not simulate the textile wastewater chemicals well. Furthermore, only a few publications focus on the long-term treatment of industrial effluents using pond systems. They have not considered the mechanisms of dye removal in detail, and there is a lack of information concerning the main water quality parameters and the system performance from an engineering point of view.

Therefore, it is required to fill the gap in knowledge by operating pond systems planted with $L$. minor to study the long-term impact of $\mathrm{pH}$ adjustment on system performance as a post-treatment stage for handling artificial textile wastewater containing azo dyes (Acid Blue 113, Reactive Blue 198, Basic Red 46 and Direct Orange 46) with the main focus on dye degradation processes.

Finally, Holkar et al. (2016) pointed out that since about 1985 , the processes of colour removal from textile factory wastewater attracted most attention. However, more recently, the main attention has shifted to sustainable technologies applied for dye mineralisation rather than for colour elimination. This highlights the importance of this research, which focuses on dye mineralisation and identifying the potentially toxic intermediate products after dye decolourisation.

\section{Aim and Objectives}

The aim of this experimental study is to assess the impact of $\mathrm{pH}$ on the treatment efficiency of azo dyes containing artificial textile wastewater using pond systems as a polishing step. The corresponding objectives are to evaluate the inflow water quality as well as the impact of plants like L. minor and algae on the dye removal and outflow water quality. The main focus is on assessing the treatment performance in terms of dye, organic matters, $\mathrm{NH}_{4}-\mathrm{N}$, nitratenitrogen (NO3-N) and ortho-phosphate-phosphorous $\left(\mathrm{PO}_{4}-\mathrm{P}\right)$ removal. However, the suitability of using specific constituents of artificial textile wastewater, and the impact of this wastewater and dyes on the plant growth rate have also been examined. 


\section{Materials and Methods}

\section{Dyes and Synthetic Textile Wastewater}

The commercial synthetic dyes used in this study were Acid Blue 113 (AB113), Reactive Blue 198 (RB198), Basic Red 46 (BR46) and Direct Orange 46 (DO46), which were applied without any purification. The authors prepared dye stock solutions by dissolving $5 \mathrm{~g}$ of each dye in $1 \mathrm{~L}$ of deionised water. The solutions were kept in total darkness at $4{ }^{\circ} \mathrm{C}$.

The artificial textile wastewater used contained a mixture of organic carbon, nutrients and buffer solution to simulate the effluents from textile factories as reported by Ong et al. (2010). The composition and concentration $\left(\mathrm{g} \mathrm{L}^{-1}\right)$ of the chemicals applied were as follows: $\mathrm{C}_{6} \mathrm{H}_{5} \mathrm{COONa}$ (0.1071), $\mathrm{CH}_{3} \mathrm{COONa}(0.2049), \mathrm{NH}_{4} \mathrm{NO} 3$ (0.1761), NaCl (0.007), $\mathrm{MgCl}_{2} \cdot 6 \mathrm{H}_{2} \mathrm{O}(0.0034), \mathrm{CaCl}_{2} \cdot 2 \mathrm{H}_{2} \mathrm{O}$ (0.004) and $\mathrm{K}_{2} \mathrm{HPO}_{4} \cdot 3 \mathrm{H}_{2} \mathrm{O}(0.0367)$. The $\mathrm{pH}$ was adjusted using $1 \mathrm{M}$ $\mathrm{NaOH}$ and $1 \mathrm{M}$ HCL solutions. All chemicals were of analytical grade and were purchased from Scientific Laboratory Supplies Ltd. (Wilford Industrial Estate, Ruddington Lane, Wilford, Nottingham, England, UK). For preparing a stock solution of synthetic wastewater, which was prepared under non-sterile conditions at a laboratory temperature of around $25{ }^{\circ} \mathrm{C}$, all chemicals were mixed with dechlorinated boiled tap water using a magnetic stirrer with a heating plate at $150 \mathrm{rpm}$ for $1 \mathrm{~h}$ to guarantee that all chemicals dissolve. In order to prepare the four influents for the pond systems, the solutions of each dye were separately mixed with the solution of the artificial wastewater and dechlorinated tap water, providing a $10 \mathrm{mg} \mathrm{L}^{-1}$ concentration for each dye.

\section{Experimental Set-Up}

The test was conducted under controlled laboratory conditions using plastic containers of $33 \mathrm{~cm}$ length, $25.5 \mathrm{~cm}$ width and $14 \mathrm{~cm}$ depth. This study links two experiments with each other. The first experiment was conducted between 1 October 2015 and 19 January 2016. The second one operated in two phases between 20 January 2016 and 30 June 2017. The first experiment assessed the treatment performance of the dyes and the impact of artificial wastewater on the plant growth. The plants were obtained from a pond near Cowpe Reservoir (Cowpe Lodge, Cowpe, Rossendale, England, UK), which had not been impacted by any source of textile effluents. The plants were carefully washed with tap water and then kept for acclimatisation under laboratory conditions for 12 days. The experiment comprised seventy-eight shallow pond simulations.
Eighteen containers were used for each dye, and further six systems had no dyes. The set-up for each dye (either AB113, RB198, BR46 or DO46) consisted of two groups of treatment: the first group contained Lemna minor L. (common duckweed) (planted ponds P1, P3 and P5) and the second group had no plants and functioned as controls (control ponds P2, P4 and P6). Three replicates were assessed for each group. The system was fed with four artificial dye wastewaters at initial dye concentrations of $10 \mathrm{mg} \mathrm{L}^{-1}$. Three different wastewater inflows for each dye were assessed: ponds without any hydrolyses at normal $\mathrm{pH}$ (inflows of $\mathrm{P} 1$ and $\mathrm{P} 2$ ), ponds with wastewater adjusted to pH 9 (inflows of $\mathrm{P} 3$ and $\mathrm{P} 4$ ) and ponds with wastewater adjusted to pH 6 (inflows of P5 and P6).

The extra six ponds were as follows: three planted ponds receiving artificial wastewater only without dye and three planted ponds receiving only tap water for comparison reasons. All pond systems were filled with artificial dye wastewater up to a depth of $6.9 \mathrm{~cm}$. This level equates to a corresponding volume of $5 \mathrm{~L}$ on 13 October 2015 as a first dose. Subsequently, 200 washed and healthy L. minor plants (about $2.6 \pm 0.03 \mathrm{~g}$ ) with approximately equal frond numbers were introduced to each system.

The $\mathrm{pH}$ values of 6 and 9 were selected, because they equate to common lower and upper $\mathrm{pH}$ discharge thresholds (Yaseen and Scholz 2016) and are within the typical range of textile effluents (Ghaly et al. 2014). The selected values are also within the tolerable $\mathrm{pH}$ range (4-9) for L. minor growth according to Movafeghi et al. (2013). Furthermore, Saratale et al. (2011) mentioned that higher microbial dye colour removal requires $\mathrm{pH}$ values between 6 and 10 as optimum and that the removal efficiency in strongly acid or alkaline environments noticeably drops. It is expected that the effects of $\mathrm{pH}$ may be related to the transport of dye molecules across the cell membrane, which is considered as the rate-limiting step for decolourisation (Saratale et al. 2011). After adding the first dose, which equals $5 \mathrm{~L}$ in each pond, the system was fed weekly by removing the water solution in each pond (manually using suction pump) until the level was equivalent to $3 \mathrm{~L}(4.4 \mathrm{~cm}$ depth) and two additional litres were supplied to keep the water level equivalent to $5 \mathrm{~L}$ again. This is because the depth equivalent to $3 \mathrm{~L}$ was enough to keep the root of $L$. minor without any contact with the base of the pond and to mimic the natural systems when the treated water is discharged to the receiving watercourses and new doses are added. The corresponding contact time was 7 days, which was similar to those times published previously (Movafeghi et al. 2013) regarding L. minor use for the purification of textile dyes. In addition, the ability of $L$. minor for the removal of dyes increased with elevated durations of contact (Reema et al. 2011).

The second experiment was operated in two phases: the first phase was between 20 January 2016 and 18 October 
2016. The set-up consisted of forty-two containers simulating shallow ponds. Eighteen containers were applied for each dye, and further six systems were maintained without the presence of dyes. All steps were similar, except for the dyes (RB198 and BR46 only) and the artificial wastewater used. The latter had a dilution ratio of 1 part of artificial wastewater to 24 parts of raw water. Such a high dilution was required, because in the first experiment, all plants eventually died due to the high concentrations of some chemicals in the artificial wastewater. The first dose of $5 \mathrm{~L}$ was added to the system on 26 January 2016, and then the system was fed weekly as explained previously.

The second phase was operated between 18 October 2016 and 30 June 2017. The influent $\mathrm{pH}$ was normal. The system comprised twenty containers: six pond systems for each dye and further eight systems for control (no dye). The setup for each dye comprised of three groups: the first group contained L. minor and algae (Pond LA). The second used only algae (Pond A). The third was without $L$. minor and/or algae as a control (Pond C). However, the ponds without dye consisted of two treatment groups: one used L. minor and algae and the other contained only algae. The experiment operated in two replicates. The experiment was conducted to evaluate the impact of the algae Oedogonium spp. Link ex Hirn, which grew naturally in all planted ponds during the last 3 months of the first phase. The first planted pond in the first phase was divided into two ponds and labelled $L$. minor and algae ponds (Pond LA). Then, the second planted pond in the first phase was divided into two ponds after completely removing $L$. minor, and the new system was labelled as algae ponds (Pond A), where only the algae were kept in the system. Regarding the control ponds, this phase was conducted by continuing to use two control ponds, which were already operated in the first phase. Note that the target concentration of each pond was established before adding the first dose of the second phase, which compensated for the water level until a volume equivalent of $5 \mathrm{~L}$ was reached. The same procedure was undertaken for the ponds without dyes. Then, the system was fed weekly as explained earlier in phase one. Note that the volume of water removed or added and their corresponding concentrations were considered in the calculations. Figure 1 presents the experiment, and Table 1 provides an overview of the operation.

\section{Plant Growth Monitoring}

The $L$. minor growth rate was monitored to assess the impact of dyes and artificial wastewater on plants. The plants were harvested when they covered all the surface area to avoid overcrowding, which negatively affects their growth. The fresh weight of harvested L. minor was recorded after cleaning the plant from any attached algae and then putting them on absorbent paper for five minutes. The corresponding dry weights were also recorded after placing the plants within an oven at $105{ }^{\circ} \mathrm{C}$ for 1 day. The relative growth rate was calculated according to the fresh biomass.

\section{Environmental Boundary Conditions}

Budmaster Osram Delux (OD) LED lamps (204 W) were used as grow lights. They were supplied by Budmaster LED (Unit 4, QHEP, Glan y Wern Road, Colwyn Bay, Gwynedd, Wales, UK). A timer controlled the light to simulate day light in Salford. The relative humidity and temperature readings were measured with the Thermometer-HygrometerStation provided by wetterladen24.de (JM Handelspunkt, Geschwend, Germany). Measurements of light were undertaken by applying the lux meter ATP-DT-1300 between 200 and 50,000 lx (TIM-STAR, Road Three, Winsford Industrial Estate, Winsford, England, UK). Readings were taken above the plants. The environmental boundary conditions are summarised in Table 2.

\section{Water Quality Analysis}

Water quality analysis of $50 \mathrm{~mL}$ samples was performed routinely according to APHA (2005), unless stated otherwise. The spectrophotometer DR 2800 Hach Lange (Hach Lange, Willstätter Strasse, Düsseldorf, Germany) was used for the determination of $\mathrm{COD}, \mathrm{NH}_{4}-\mathrm{H}, \mathrm{PO}_{4}-\mathrm{P}, \mathrm{NO}_{3}-\mathrm{N}$, absorbance, apparent colour and SS. Turbidity was recorded with a Turbicheck Turbidity Meter (Tintometer, Lovibond Water Testing, Dortmund, Germany). The redox potential (redox) and $\mathrm{pH}$ were obtained with a WTW Vario meter (Cole-Parmer Instrument Company, Trumpers Way, Hanwell, London, England, UK). Dissolved oxygen was measured with a Hach HQ30d flexi meter (Hach, Pacific Way, Salford, England, UK). Both EC and TDS were recorded by a METTLER TOLEDO Five $\mathrm{Go}^{\mathrm{TM}}$ meter (Keison Products, Chelmsford, England, UK). The dye concentrations for filtered samples of $12 \mathrm{~mL}$ each were measured by the absorbance corresponding to the maximum wavelength using calibration curves. The Varian Cary 300 ultraviolet (UV)-Vis spectrophotometer with a range between 200 and $800 \mathrm{~nm}$ (www.varianinc.com) was used. A quartz cuvette of $10 \mu \mathrm{L}$ was applied to analyse outflow samples.

High-performance liquid chromatography (HPLC) analysis was used for organic molecule (dyes and their metabolites) separation by monitoring the peak area, if it disappeared or shifted towards lower retention time. The test was carried out (Agilent 1260) on a HiChrom excel C18 column ( $4.3 \mathrm{~mm}$ to $250 \mathrm{~mm} ; 1.7 \mu \mathrm{m}$ particles). Acetonitrile (70\%) and water $(30 \%)$ were used at a flow rate of $1.3 \mathrm{~L} \mathrm{~min}^{-1}$. The UV detector was kept at the maximum wavelength for each dye. Aqueous samples of $20 \mu \mathrm{L}$ were injected manually into the injector port using a microlitre syringe. 
Fig. 1 a Diagrams of the experimental set-up phases: $\mathbf{i}$ first experiment, ii second experiment (first phase) and iii second experiment (second phase) and b overview of the experimental procedure. AB113, Acid Blue

113; RB198, Reactive Blue 198; BR46, Basic Red 46; DO46, Direct Orange 46; AWW, artificial wastewater; P1, planted ponds receiving inflow at normal $\mathrm{pH}$; $\mathrm{P} 2$, unplanted ponds receiving inflow at normal $\mathrm{pH}$; $\mathrm{P} 3$, planted ponds receiving inflow at $\mathrm{pH}$ of $9 ; \mathrm{P} 4$, unplanted ponds receiving inflow at $\mathrm{pH}$ of 9; $\mathrm{P} 5$, planted ponds receiving inflow at $\mathrm{pH}$ of 6; $\mathrm{P} 6$, unplanted ponds receiving inflow at $\mathrm{pH}$ of 6; Pond C: unplanted pond; Pond A: algae pond; Pond LA: L. minor and algae pond; FW, fresh weight; DW, dry weight; RGR, relative growth rate; $\mathrm{NaOH}$, sodium hydroxide; $\mathrm{HCl}$, hydrogen chloride; SPSS, Statistical Package for the Social Sciences; GCMS, gas chromatography-mass spectrometry; HPLC, high-performance liquid chromatography; UV, ultraviolet; COD, chemical oxygen demand; $\mathrm{NH}_{4}-\mathrm{N}$, ammonium-nitrogen; $\mathrm{NO}_{3}-\mathrm{N}$, nitrate-nitrogen; $\mathrm{PO}_{4}-\mathrm{P}$, orthophosphate-phosphorus; EC, electric conductivity; TDS, total dissolved solids; SS, suspended solids

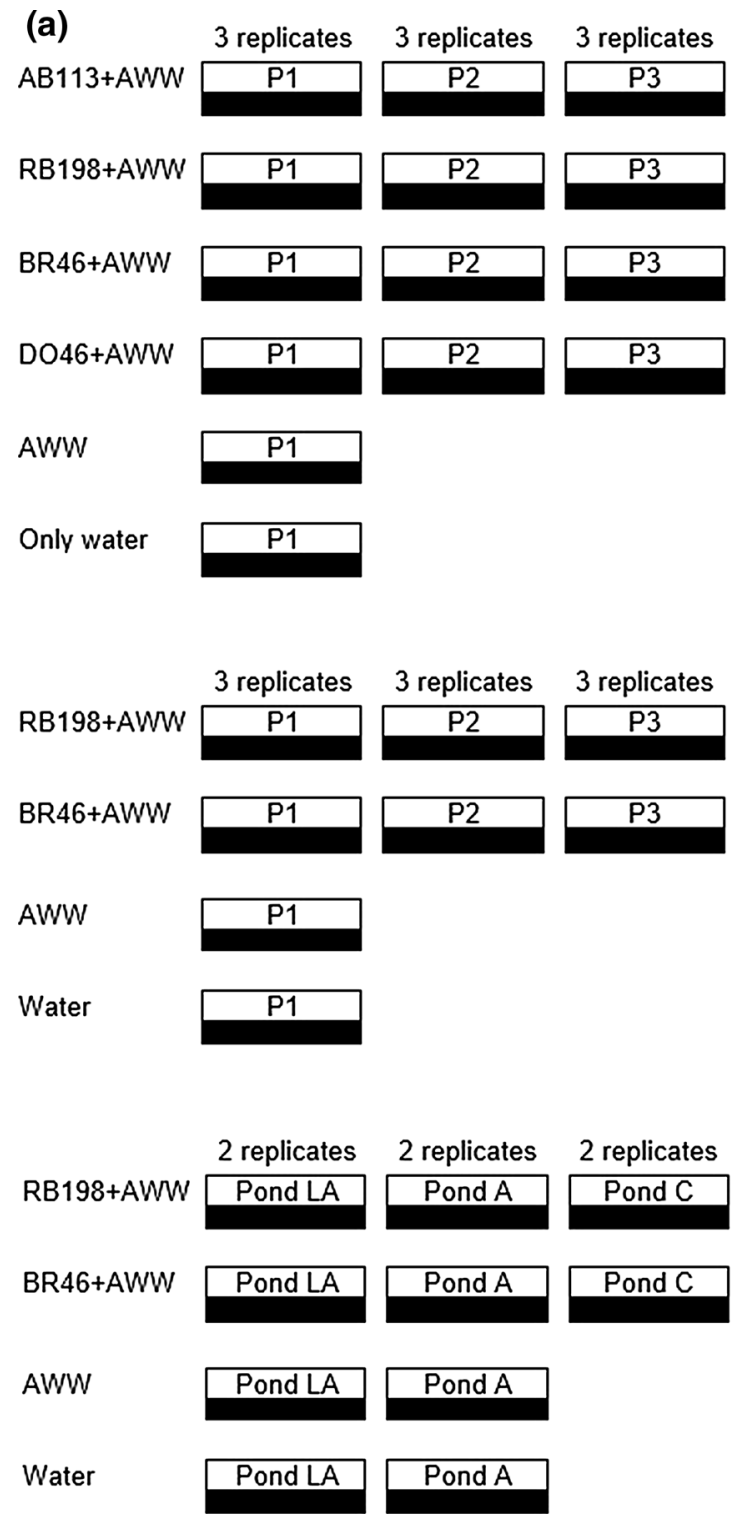

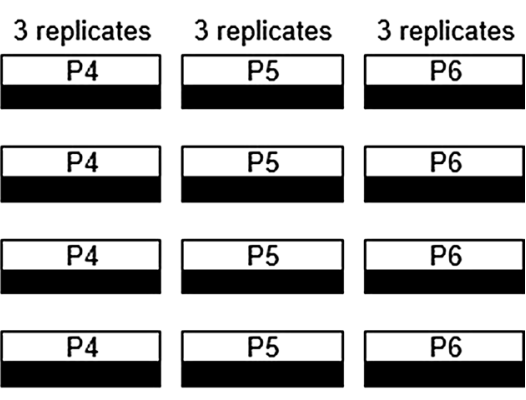

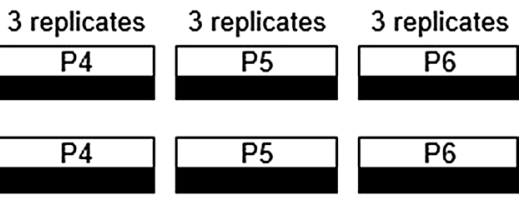

A gas chromatography-mass spectrometry (GC-MS) test was carried out for identification of the intermediate products of aromatic amines after treatment. Aqueous samples of $1 \mathrm{~L}$ each in glass bottles were sent to Concept Life Sciences Analytical \& Development Services Limited (Hadfield House, Hadfield Street, Cornbrook, Manchester, England, UK) for external analysis.

\section{Numerical Analysis}

The standard software Microsoft Excel (www.microsoft. com) was used. The IBM Statistical Package for the Social Sciences (SPSS) Statistics, version 22 (www.ibm.com), was applied to calculate the nonparametric Kruskal-Wallis $(p<0.05)$ and Mann-Whitney $U$ tests for the non-normally distributed variables. The parametric one-way ANOVA using the Tukey HSD post hoc multiple comparison test and the $t$ test were used for computing the normally dependent variables. The Shapiro-Wilk test was performed to assess whether data were normally distributed. The Spearman test was applied to determine the correlation coefficients of nonparametric parameters.

\section{Results and Discussion}

\section{First Experiment}

\section{Overall Treatment Performance}

The mean inflow characteristics of the undiluted artificial wastewater used in this experiment were as follows: $\mathrm{pH}$ 
Fig. 1 (continued)

(b)

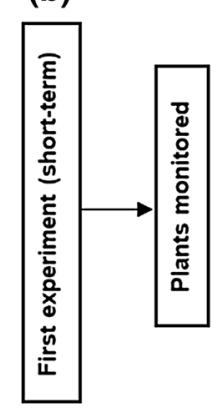

Performance (subject to $\mathrm{pH}$ ) of 78 shallow pond
systems treating AWW contaminated with azo

dyes AB113, RB198, BR46 and DO46

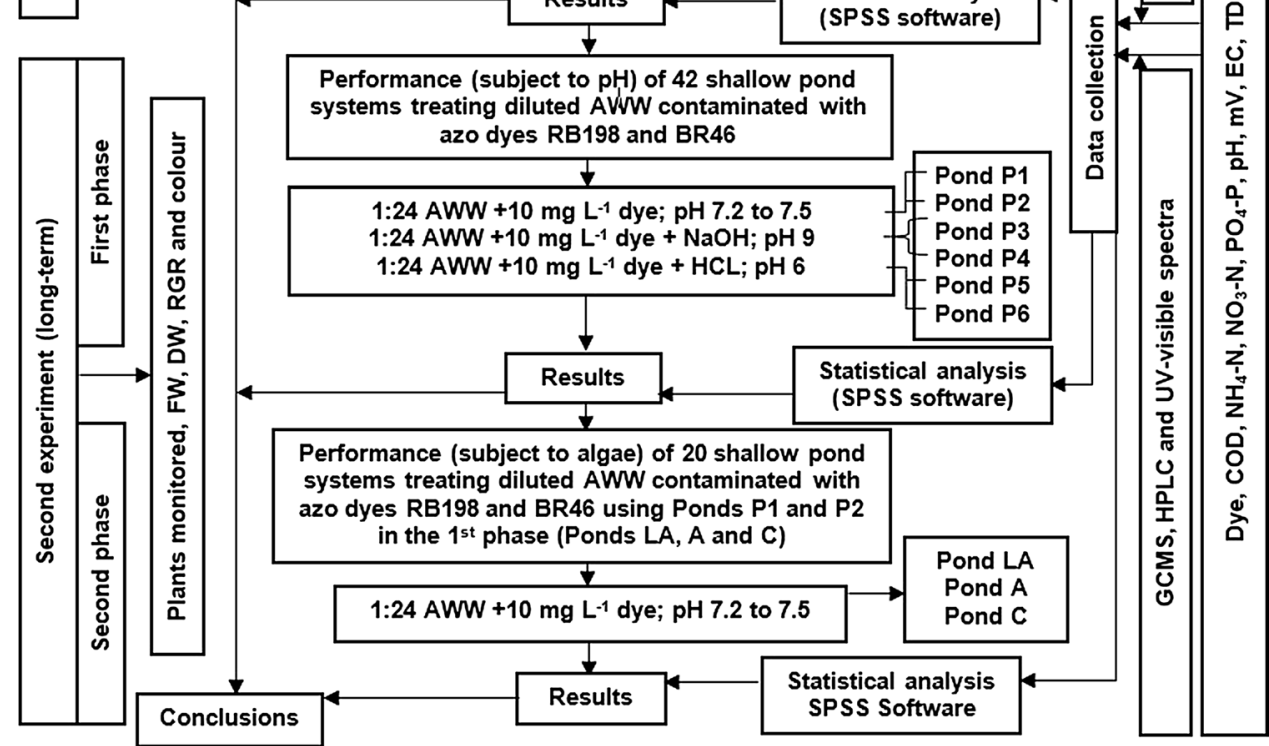

Table 1 Experimental periods and details

\begin{tabular}{llc}
\hline Stage & Duration & Notes \\
\hline First experiment & 1 October 2015 to 19 January 2016 & $\begin{array}{c}78 \text { ponds for the treatment of the dyes AB113, RB198, BR46 and } \\
\text { DO46 using artificial wastewater and clean water at a ratio of 1:1 } \\
\text { Second experiment (first phase) } \\
\text { 20 January 2016 to 18 October 2016 for the treatment of the dyes RB198 and BR46 at normal, } \\
\text { basic and acidic conditions using artificial wastewater and clean } \\
\text { water at a ratio of 1:24 } \\
\text { 20 ponds for the treatment of the dyes RB198 and BR46 at normal } \\
\text { conditions using artificial wastewater and clean water at a ratio } \\
\text { of 1:24 }\end{array}$ \\
\hline
\end{tabular}

AB113 Acid Blue 113, RB198 Reactive Blue 198, BR46 Basic Red 46, DO46 Direct Orange 46

(7.5), redox potential $(-38.9 \mathrm{mV})$, DO $\left(8.5 \mathrm{mg} \mathrm{L}^{-1}\right)$, EC $\left(714.8 \mu \mathrm{sm}^{-1}\right)$, TDS $\left(357.4 \mathrm{mg} \mathrm{L}^{-1}\right)$, SS $\left(7 \mathrm{mg} \mathrm{L}^{-1}\right)$, turbidity (3.5 NTU), apparent colour (30.8 Pt-Co), COD (366 mg L $\left.{ }^{-1}\right), \mathrm{NH}_{4}-\mathrm{N}\left(33.7 \mathrm{mg} \mathrm{L}^{-1}\right), \mathrm{NO}_{3}-\mathrm{N}\left(31.1 \mathrm{mg} \mathrm{L}^{-1}\right)$ and $\mathrm{PO}_{4}-\mathrm{P}\left(7.5 \mathrm{mg} \mathrm{L}^{-1}\right)$. The mean inflow values of $\mathrm{pH}$, COD and colour were within the typical characteristics of textile wastewater ranges (Ghaly et al. 2014). However, $\mathrm{NH}_{4}-\mathrm{N}$ and $\mathrm{NO}_{3}-\mathrm{N}$ values were higher. The initial dye concentration was $10 \mathrm{mg} \mathrm{L}^{-1}$, which was at the lower end of dye effluents (10-250 $\mathrm{mg} \mathrm{L}^{-1}$ ) as mentioned by Ghaly et al. (2014). Regarding SS and TDS, the mean values were lower than the typical range. Supplementary materials 1 and 2 show the inflow and outflow water quality parameters related to this experiment, respectively. Figures 2 and 3 highlight the dye removal efficiency and the spectral data for this experiment. More information about the treatment performance of the dyes is provided Supplementary material 3a.

\section{Plant Monitoring}

The plants within the system were monitored regularly, and during the first 2 weeks of adding artificial dye wastewater, 
Table 2 Overview of environmental boundary conditions in the laboratory

\begin{tabular}{|c|c|c|c|c|c|c|}
\hline Parameter & Unit & Mean & Standard deviation & Minimum & Maximum & Number \\
\hline \multicolumn{7}{|l|}{ First experiment } \\
\hline Temperature & ${ }^{\circ} \mathrm{C}$ & 28.0 & 0.58 & 26.7 & 28.8 & 74 \\
\hline Temperature (minimum within $24 \mathrm{~h}$ ) & ${ }^{\circ} \mathrm{C}$ & 24.8 & 1.22 & 22.8 & 28.5 & 74 \\
\hline Temperature (maximum within $24 \mathrm{~h}$ ) & ${ }^{\circ} \mathrm{C}$ & 28.6 & 0.24 & 28.0 & 29.1 & 74 \\
\hline Relative humidity & $\%$ & 50.5 & 2.46 & 46.0 & 60.0 & 74 \\
\hline Relative humidity (minimum within 24 h) & $\%$ & 47.8 & 3.34 & 42.0 & 58.0 & 74 \\
\hline Relative humidity (maximum within $24 \mathrm{~h}$ ) & $\%$ & 57.3 & 3.76 & 46.0 & 66.0 & 74 \\
\hline Illuminance (one-off records) & $\operatorname{lux}$ & 6995.7 & 345.80 & 6430.0 & 7721.0 & 58 \\
\hline \multicolumn{7}{|l|}{ Second experiment (first phase) } \\
\hline Temperature & ${ }^{\circ} \mathrm{C}$ & 24.5 & 1.87 & 21.2 & 28.5 & 174 \\
\hline Temperature (minimum within $24 \mathrm{~h}$ ) & ${ }^{\circ} \mathrm{C}$ & 22.0 & 1.82 & 18.5 & 26.9 & 174 \\
\hline Temperature (maximum within $24 \mathrm{~h}$ ) & ${ }^{\circ} \mathrm{C}$ & 25.4 & 2.20 & 20.4 & 28.9 & 174 \\
\hline Relative humidity & $\%$ & 61.8 & 7.39 & 48.0 & 76.0 & 174 \\
\hline Relative humidity (minimum within 24 h) & $\%$ & 58.9 & 8.99 & 41.0 & 74.0 & 174 \\
\hline Relative humidity (maximum within 24 h) & $\%$ & 68.3 & 7.62 & 50.0 & 84.0 & 174 \\
\hline Illuminance (one-off records) & $\operatorname{lux}$ & 6962.1 & 354.17 & 6220 & 7735 & 98 \\
\hline \multicolumn{7}{|l|}{ Second experiment (second phase) } \\
\hline Temperature & ${ }^{\circ} \mathrm{C}$ & 23.3 & 1.85 & 19.4 & 26.8 & 171 \\
\hline Temperature (minimum within $24 \mathrm{~h}$ ) & ${ }^{\circ} \mathrm{C}$ & 21.7 & 1.42 & 17.4 & 26.9 & 171 \\
\hline Temperature (maximum within $24 \mathrm{~h}$ ) & ${ }^{\circ} \mathrm{C}$ & 23.7 & 3.01 & 18.1 & 26.9 & 171 \\
\hline Relative humidity & $\%$ & 64.0 & 4.05 & 51.0 & 73.0 & 171 \\
\hline Relative humidity (minimum within $24 \mathrm{~h}$ ) & $\%$ & 61.9 & 4.49 & 44.0 & 70.0 & 171 \\
\hline Relative humidity (maximum within 24 h) & $\%$ & 69.9 & 5.47 & 53.0 & 80.0 & 171 \\
\hline Illuminance (one-off records) & $\operatorname{lux}$ & 6853.5 & 382.90 & 6335 & 7722 & 94 \\
\hline
\end{tabular}

Fig. 2 Mean dye removal efficiency during the experiment period between 1 October 2015 and 19 January 2016. P1, planted ponds receiving inflow at normal $\mathrm{pH} ; \mathrm{P} 2$, unplanted ponds receiving inflow at normal $\mathrm{pH} ; \mathrm{P} 3$, planted ponds receiving inflow at $\mathrm{pH}$ of 9 ; $\mathrm{P} 4$, unplanted ponds receiving inflow at $\mathrm{pH}$ of $9 ; \mathrm{P} 5$, planted ponds receiving inflow at $\mathrm{pH}$ of 6; P6, unplanted ponds receiving inflow at $\mathrm{pH}$ of 6 ; AWW: artificial wastewater

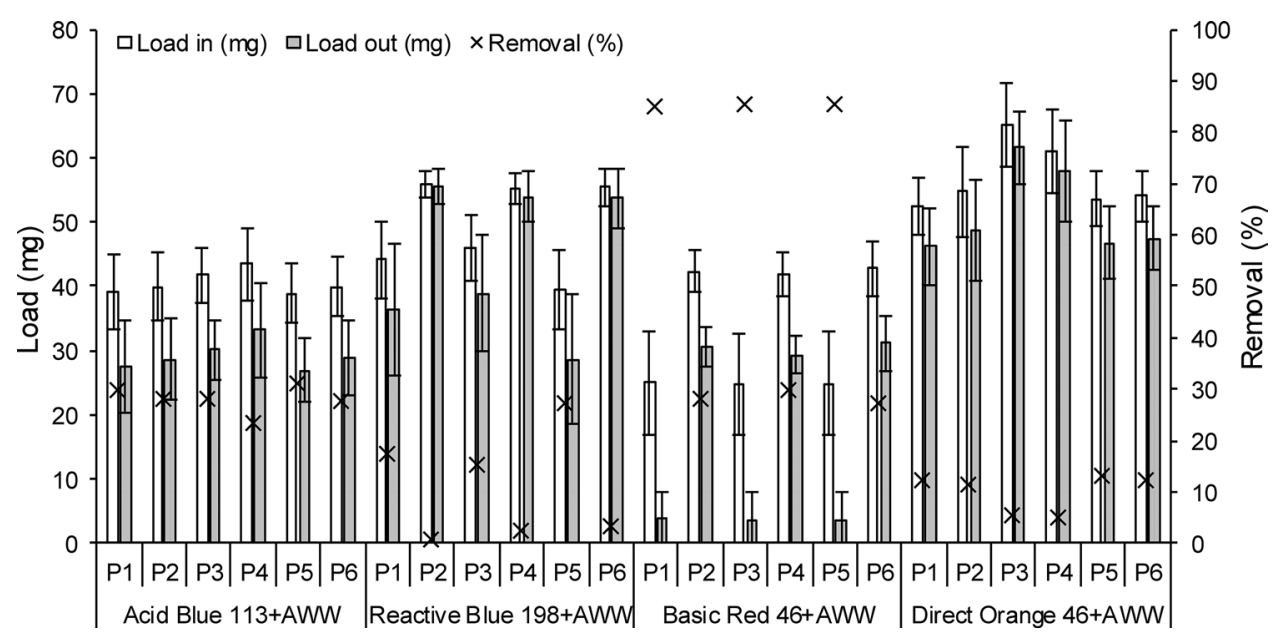

they were still green and their number started to increase, but they did not cover the entire surface area. Thereafter, the green colour faded (reduced). In week 4, the colour of the fronds of $L$. minor turned yellow and subsequently brown for all ponds with and without dyes except for ponds containing only tap water. This indicated that the high concentrations of chemicals in the artificial wastewater negatively impacted plant growth. At the end of the experiment, some of the fronds remained brown, but most of them turned white. The dead plants settled in the pond or stuck on the sides of the ponds.

The death of the plants was an indication of the toxicity such as the high ammonium concentration of the artificial wastewater. However, the dead plant biomass contributed to the treatment performance during the operation period. Therefore, it was advisable to re-examine the wastewater 
Fig. 3 Ultraviolet visible analysis for the outflow samples at the end of the experimental rig, which was operated between 1 October 2015 and 19 January 2016: $\mathbf{a}, \mathbf{b}$ and $\mathbf{c}$ ponds treating the dye Acid Blue 113 at normal, alkaline and acidic conditions in this order; $\mathbf{d}, \mathbf{e}$ and $\mathbf{f}$ ponds treating the dye Reactive Blue 198 at normal, alkaline and acidic conditions, respectively; $\mathbf{g}, \mathbf{h}$ and $\mathbf{i}$, ponds treating the dye Basic Red 46 at normal, alkaline and acidic conditions in this order; and $\mathbf{j}, \mathbf{k}$ and $\mathbf{I}$ ponds treating the dye Direct Orange 46. IF, inflow; P1, outflow of planted ponds; $\mathrm{P} 2$, outflow of unplanted ponds
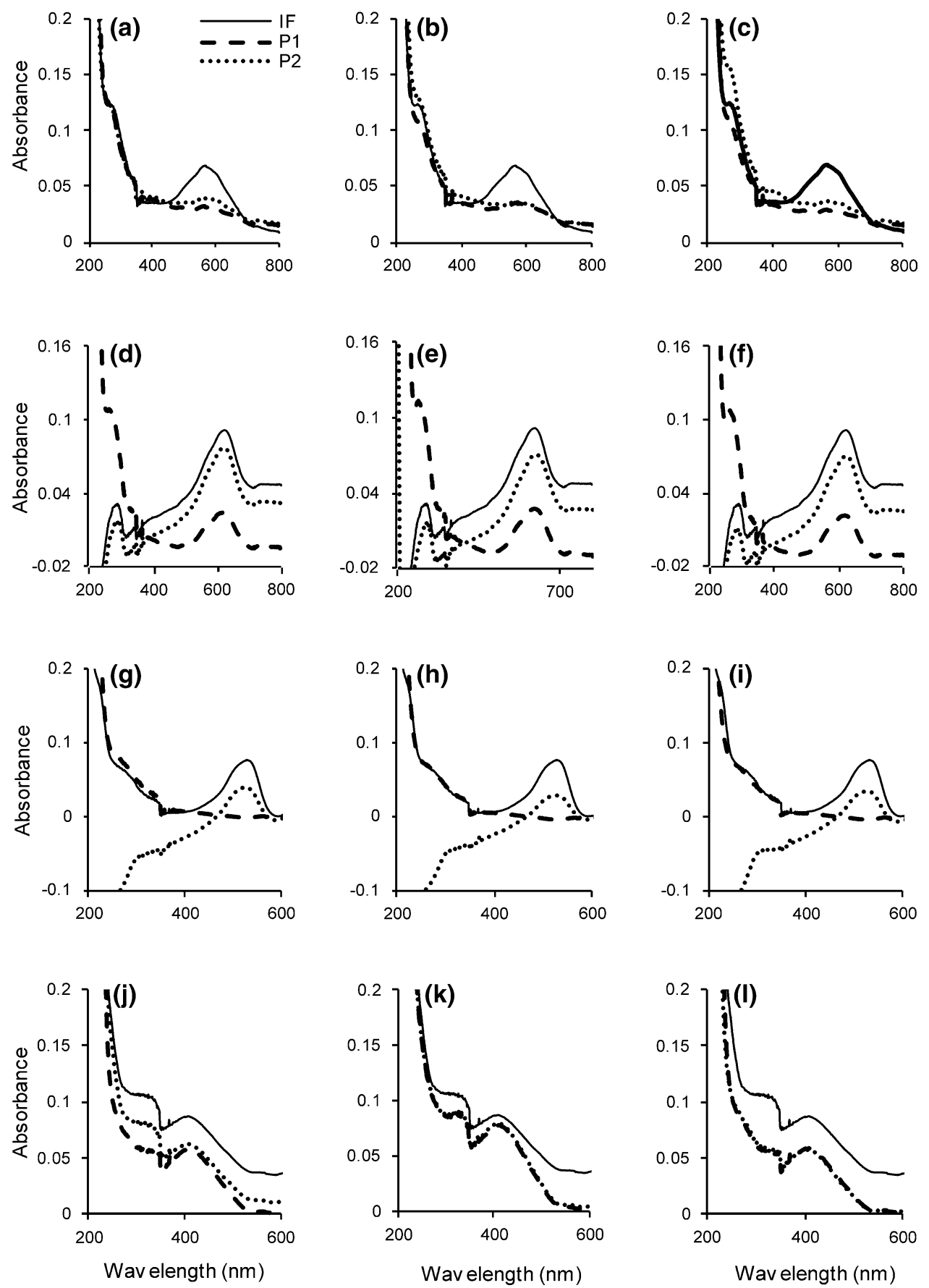

constituents for different dilution ratios. The dilution of one part of artificial wastewater to twenty-four parts of raw water was seen as appropriate for the plants to survive.

\section{Second Experiment}

\section{Overview of the Inflow Water Quality}

Supplementary material 4 summarises the values of the inflow characteristics regarding the artificial wastewater after dilution with and without dyes for both the first and second phases of the second experiment. The mean inflow values of $\mathrm{pH}$, colour, $\mathrm{NO}_{3}-\mathrm{N}$ and $\mathrm{NH}_{4}-\mathrm{N}$ were within the typical characteristics of textile wastewater. The initial dye concentration was $10 \mathrm{mg} \mathrm{L}^{-1}$ and was regarded to be within the lower range of dye effluents $\left(10-250 \mathrm{mg} \mathrm{L}^{-1}\right)$. Regarding COD, SS and TDS, the mean inflow values were lower than the typical ones (Ghaly et al. 2014). The wastewater used in this study was suitable for operating pond systems as a polishing step (last treatment in 
a multi-stage treatment train systems), which deals with wastewater in relatively low concentrations (Yaseen and Scholz 2016).

\section{Outflow Water Quality Parameters (Phase 1)}

Supplementary material 5 summarises the overall outflow water quality parameters in each system for the second experiment (first phase) between 20 January 2016 and 18 October 2016. Figure 4 shows the mean removal efficiencies
Fig. 4 Mean removal efficiencies during the experiment period between 20 January 2016 and 18 October 2016: a dyes; $\mathbf{b}$ chemical oxygen demand; c ammonium-nitrogen; d nitrate-nitrogen; and e orthophosphate-phosphorous. AWW, artificial wastewater; TW, tap water; P1, planted ponds receiving inflow at normal $\mathrm{pH}$; $\mathrm{P} 2$, unplanted ponds receiving inflow at normal $\mathrm{pH} ; \mathrm{P} 3$, planted ponds receiving inflow at $\mathrm{pH}$ of $9 ; \mathrm{P} 4$, unplanted ponds obtaining inflow at $\mathrm{pH}$ of 9 ; $\mathrm{P} 5$, planted ponds receiving inflow at $\mathrm{pH}$ of $6 ; \mathrm{P} 6$, unplanted ponds receiving inflow at $\mathrm{pH}$ of 6
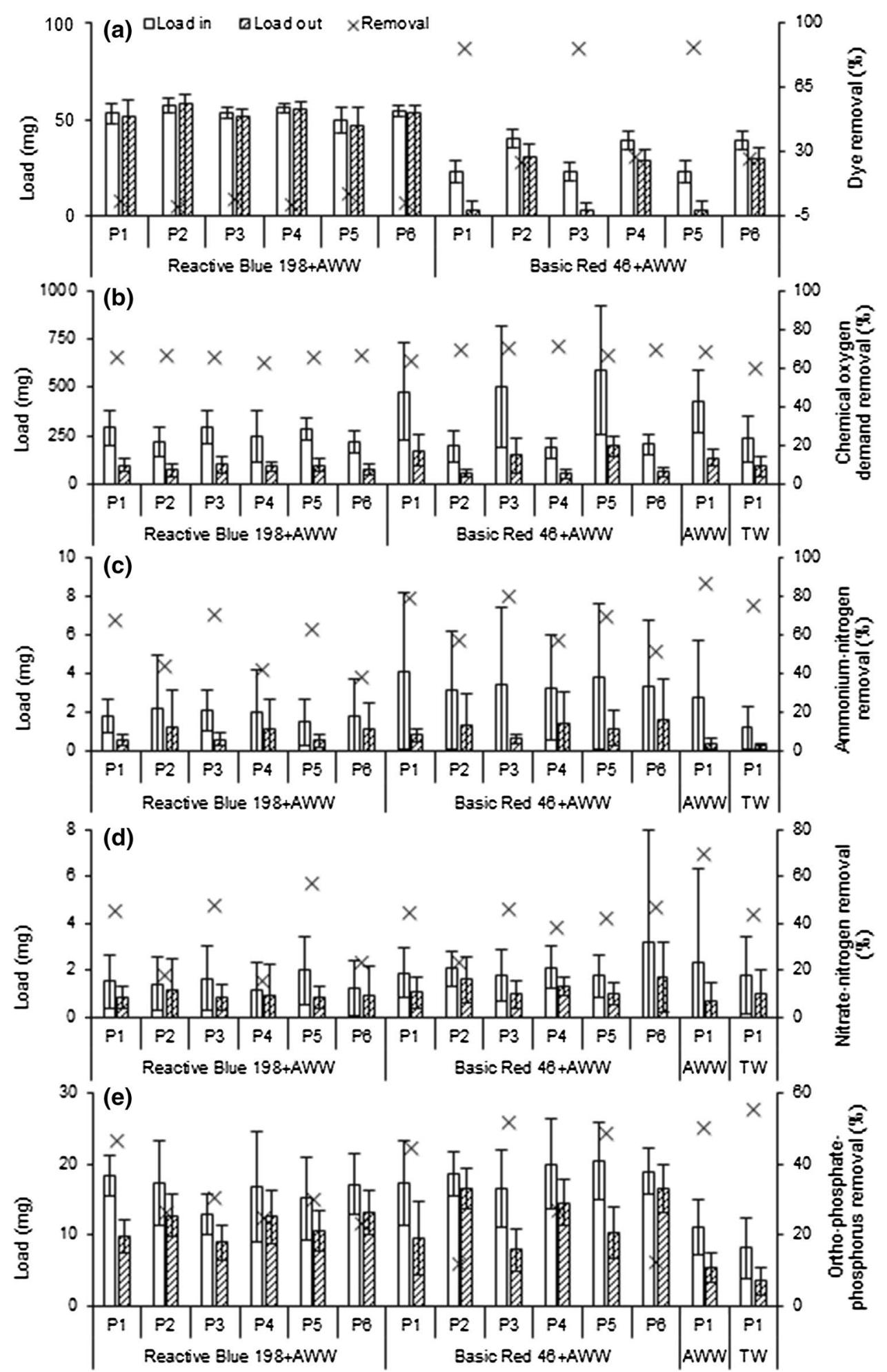
Fig. 5 Ultraviolet visible analysis for the outflow samples at the end of the second experiment (first phase); $\mathbf{a}, \mathbf{b}$ and $\mathbf{c}$ ponds treating Reactive Blue 198 at normal, alkaline and acidic conditions, respectively; $\mathbf{d}, \mathbf{e}$ and $\mathbf{f}$, ponds treating Basic Red 46 at normal, alkaline and acidic conditions in this order. IF, inflow; P1, outflow of the planted ponds; $\mathrm{P} 2$, outflow of the unplanted ponds
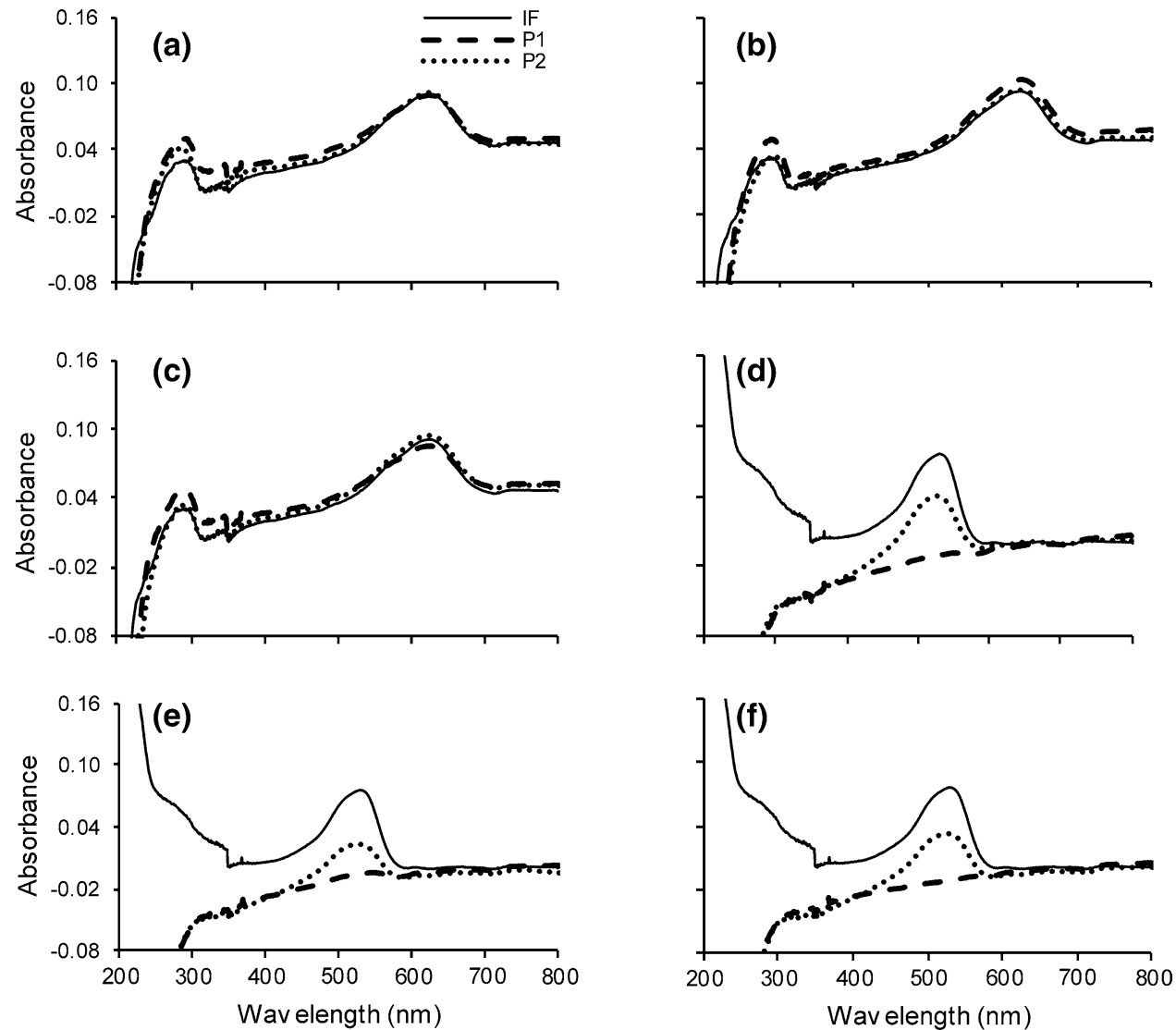

of the dyes, COD and nutrients for each system related to the first phase of the second experiment lasting between 20 January 2016 and 18 October 2016. Figure 5 shows the UV-Vis analysis for the inflow and outflow samples for each dye linked to the first phase of the second experiment.

Based on dye removal, findings showed that although the mean removal of RB198 was very low for all ponds, significant differences were found (Mann-Whitney $U, p<0.05$ ) between planted and unplanted ponds in case of high (P3 and P4) and low (P5 and P6) pH (Fig. 4a) attributed to the impact of the plants in the system. This low removal can be explained by the presence of two sulphonic groups, high molecular weight and the complex structure of RB198 making this dye challenging to degrade (Yaseen and Scholz $2017 \mathrm{a}, \mathrm{b})$. The mean removal at acidic conditions was significantly (Kruskal-Wallis, $p<0.05$ ) higher than those at normal conditions, indicating that the adsorption capacity increased at low $\mathrm{pH}$. This is because at acidic conditions, the positive charge in the solution increased and the adsorbent surface appears positively charged. Therefore, the adsorption of an anionic dye (RB198) will lead to the decrease in RB198 concentration and consequently boost the removal efficiency (Salleh et al. 2011).

Findings indicate that the mean RB198 removal for the first experimental period lasting 3 months (Fig. 2) was higher than for the operation of 9 months during the second experiment (Fig. 4a), which highlights that time has a significant impact on RB198 removal. This is because the adsorbent property of the plant has limited capacity for RB198 molecule adsorption, which can be noticed by the higher removal during the first few weeks of the operation period for both experiments (data not shown).

In contrast, a high mean removal efficiency was noticed for the dye BR46 (Fig. 4a). The treatment performance for planted ponds was significantly (Mann-Whitney $U$, $p=0.000$ ) higher than the corresponding one for unplanted ponds, although the unplanted ponds had removal of more than $24 \%$. This result was seen as evidence that the plant has a significant contribution to BR46 removal. This high removal was attributed to the BR46 characteristics of low molecular weight, simple structure and the absence of sulphonic groups, which all improved dye elimination (Yaseen and Scholz 2017a, 2018). These results matched those by Yaseen and Scholz (2016) for the treatment of BR46 at inflow concentrations of $5 \mathrm{mg} \mathrm{L}^{-1}$ using stagnant ponds.

The impact of inflow at acidic and alkaline $\mathrm{pH}$ values on the treatment of BR46 showed no significant dissimilarity (Kruskal-Wallis, $p>0.05$ ) compared with the normal $\mathrm{pH}$ for both the unplanted and planted wetlands. Although the reduction of cationic dye increased at alkaline conditions and 
vice versa (Salleh et al. 2011), it seems that the selected $\mathrm{pH}$ values of 6 and 9 in this study had no considerable impact on the treatment of this dye as discussed in Supplementary material 3a. Similar outcomes by Movafeghi et al. (2013) were confirmed. It is important to mention that in June 2016, algae started to appear in the ponds planted with $L$. minor. These algae belonged to Oedogonium, which was identified by the Culture Collection of Algae and Protozoa (SAMS UK). Oedogonium are green and sexual species, which live in calm and freshwater either free-floating or attached to macrophytes. Therefore, it was necessary to find the impact of this kind of algae on the system performance as will be explained later on in the second phase.

The treatment performance in terms of the outflow dye concentrations (Supplementary material 5) showed that the average outflow concentrations of RB198 were higher than those of the corresponding inflow values, reflecting very low dye removal except for the planted ponds at acidic conditions, which were similar. In addition, the mean outflow RB198 concentrations at acidic conditions were significantly lower (Kruskal-Wallis, $p<0.05$ ) than those at normal conditions for planted ponds due to enhanced RB198 removal at low pH. Salleh et al. (2011) indicated that at acidic conditions, the positive charge in the solution interface increases and the adsorbent surface appears positively charged, which results in an increase in anionic dye adsorption and a decrease in cationic dye adsorption. Therefore, in case of the anionic dye RB198, the concentration will decrease and, subsequently, the removal efficiency will increase. However, lower mean outflow concentrations compared to the inflow for all ponds comprising BR46 were noticed. Planted ponds displayed mean outflow values that were significantly (Mann-Whitney $U, p<0.05$ ) reduced compared to those of the unplanted ponds without any impact on $\mathrm{pH}$. These results confirm removal efficiencies discussed above. A correlation analysis showed that the dye concentration significantly (Spearman's, $r=-0.910, p=0.000$ ) correlated negatively with the removal efficiency of dyes.

The spectral changes between the treated and untreated samples indicate modifications to the dye molecule structure after treatment. The spectrum in the visible region (400-800 nm) shows peaks of the inflow samples at 625 and $530 \mathrm{~nm}$ of RB198 and BR46, respectively, which are linked to the chromophore groups of the dye molecules. However, for the outflow samples, the intensity of the dye adsorption peak at $625 \mathrm{~nm}$ (Fig. 5a, b, and c) does not change for both planted and unplanted ponds confirming the un-decolourisation of RB198 and the increase in outflow concentrations. The dye BR46 (Fig. 5d, e and f) showed appreciable disappearances for the peak at $530 \mathrm{~nm}$ for all planted ponds, confirming the complete decolourisation and decreases in the outflow concentrations. However, control ponds showed a reduction in the peak at $530 \mathrm{~nm}$ indicating a decrease in the outflow concentration due to microbial bio-sorption processes.

The HPLC chromatogram (data not shown) showed a peak at a retention time of 1.505 min for RB198 influent. However, the peak for the outflow samples shifted to 1.53 and $1.566 \mathrm{~min}$ at normal $\mathrm{pH}, 1.552$ and $1.593 \mathrm{~min}$ at alkaline, and 1.541 and $1.557 \mathrm{~min}$ at acidic conditions for planted and unplanted ponds, respectively. These changes are due to the interaction between the artificial wastewater and the dye, because the main peak of RB198 at $625 \mathrm{~nm}$ does not change (Fig. 5a, b and c) and the removal of this dye was not achieved (Fig. 4; outflow samples are also coloured). The inflow BR46 showed peaks at retention times of 1.488, 1.693, 2.569 and $2.405 \mathrm{~min}$. However, the outflow samples for the planted ponds indicated the appearance of a new peak in the HPLC chromatogram results of the metabolites at 1.938, 1.919 and 1.908 min for normal, high and low $\mathrm{pH}$ values, respectively. In addition, all inflow peaks disappeared, which confirms the formation of new products. However, the outflow samples of unplanted ponds showed that the inflow peak at 1.693 min shifted to $1.736,1.732$ and $1.768 \mathrm{~min}$ for normal, high and low $\mathrm{pH}$ values, respectively. The presence of new peaks in the outflow samples as a result of new products indicates that the dye removal was due to phyto-transformation by plants (Khandare et al. 2011) and bio-transformation by microbes (Tahir et al. 2016).

Therefore, according to HPLC data linked to the dye BR46 removal and UV spectra results, it seems that the dye BR46 is removed in L. minor ponds due to phyto-transformation (Kabra et al. 2012), adsorption and/or accumulation processes, and potentially also by bio-transformation processes (Kagalkar 2011). However, the mechanism of BR46 removal in the control ponds was mainly due to microbial bio-sorption (Pearce et al. 2003) and potentially also biotransformation (Tahir et al. 2016) processes.

Mean outflow COD concentrations (Supplementary material 5) were not as high, if compared to the corresponding inflow concentrations (Supplementary material 4) for all ponds containing RB198, which indicates high microbial activities for COD degradation as shown in Fig. 4b. In addition, no significant differences were found between planted and unplanted ponds in terms of COD outflow concentrations ( $t$ test, $p>0.05$ ) and removal efficiency ( $t$ test, $p>0.05)$. These results indicate that COD removal was due to microbial biodegradation and the impact of the plants was negligible. Similar findings were presented previously (Ong et al. 2009). The mean COD outflow concentrations related to ponds treating BR46 (Supplementary material 5) were higher than the mean inflow concentrations for planted ponds and lower than the average inflow for unplanted ponds (Supplementary material 4). In addition, the outflow concentrations linked to the planted wetlands were significantly (Mann-Whitney $U, p<0.05$ ) higher than those for ponds 
without plants. This may be ascribed to the high percentage of BR46 decolourisation and degradation in planted ponds, which consequently increase the organic load. The death of some plants during their life cycle also increased the COD concentrations in planted compared to the unplanted systems (Dalu and Ndamba 2003). However, COD removal (Fig. 4b) for both ponds with and without plants comprising BR46 showed no significant dissimilarity ( $t$ test, $p>0.05$ ), suggesting that there was no contribution by plants in terms of organic matter uptake, and COD degradation was due to micro-organism activities (Ong et al. 2009). No significant (one-way ANOVA, $p>0.05$ ) differences were found among the outflow concentrations and the removal values concerning COD in terms of $\mathrm{pH}$ adjustment. Results indicate that the impact of different $\mathrm{pH}$ values used in this study was mostly negligible. The results of COD removal in this study do not match with the very low removal observed by Yaseen and Scholz (2016) using the same macrophytes. This may be due to the stagnant ponds used. According to common international standards, the limits for COD are around $125 \mathrm{mg} \mathrm{L}^{-1}$ for direct discharge to watercourses. The results have shown that all outflow COD values for each system were less than the standard threshold.

The main role for nitrogen removal is nitrification and denitrification, which depends mainly on temperature, $\mathrm{pH}$ and dissolved oxygen content in pond systems. In addition, nitrogen is also taken up by plants and algae.

All planted ponds showed mean outflow $\mathrm{NH}_{4}-\mathrm{N}$ values (Supplementary material 5) lower than the inflow concentrations (Supplementary material 4). However, unplanted ponds showed higher values than the corresponding mean inflows. These results are confirmed by $\mathrm{NH}_{4}-\mathrm{N}$ removal efficiencies, which were significantly ( $t$ test, $p<0.05$ ) higher in planted ponds than the corresponding unplanted ones for all systems (Fig. 4c). Results indicate that the uptake of nitrogen by plants was one of the main reasons for nitrogen reduction in this study. Kadlec et al. (2000) clarified that the impact of plants does not exceed $10 \%$ of the total removal in treatment systems. However, Ong et al. (2009) mentioned that some researchers found higher removals of $\mathrm{NH}_{4}-\mathrm{N}$ in planted than in unplanted reactors, and others did not find any differences at all. Findings highlight that $L$. minor takes up nitrogen from municipal wastewater within pond systems.

The plants removed $\mathrm{NH}_{4}-\mathrm{N}$ in the second experiment compared with the negligible removal in the first experiment (data not shown), which could be attributed to the low loading rate of $\mathrm{NH}_{4}-\mathrm{N}$ in diluted artificial wastewater, which increased the uptake level. The algae grown in this operation and the high plant survival rate contributed to good nitrogen removal as well. High $\mathrm{NH}_{4}-\mathrm{N}$ removal was also due to biological oxidation of the ammonia to nitrate with nitrite as an intermediate by nitrifying bacteria. This process required oxygen supplied by the atmosphere, diffusion and/or plant transfer via their roots.

Note that the temperature conditions and the $\mathrm{pH}$ values were within the range of possible nitrification (Kadlec et al. 2000; Ozengin and Elamic 2007). Regarding the impact of $\mathrm{pH}$, removal at low $\mathrm{pH}$ conditions was lower than at other conditions although no significant differences (one-way ANOVA, $p>0.05$ ) were found. Normally, in the presence of L. minor or algae in pond systems at high $\mathrm{pH}(8-9)$ values, nitrogen removal increases, because of boosted sedimentation and ammonia volatilisation processes. The limited density of $L$. minor at higher $\mathrm{pH}$ values leads to an increase in nitrogen accumulation within the sediment comprising decaying $L$. minor. The reduced covered surface area consequently allowed for enhanced volatilisation processes to take place. A greater dispersal of algal biomass taking up nitrogen is due to high light penetration and favourable growth conditions for algae. The $\mathrm{NH}_{4}-\mathrm{N}$ removal efficiency of ponds containing only artificial wastewater without dyes was higher than those for all ponds containing dyes. This is due to the impact of dyes and aromatic amine intermediates. The latter inhibits the nitrification activities by microbes in the system leading to a low $\mathrm{NH}_{4}-\mathrm{N}$ removal efficiency as discussed by Ong et al. (2009). No thresholds have been set for $\mathrm{NH}_{4}-\mathrm{N}$ that have relevance for the treatment system in this study (UK Government 1994). However, the standard limit relating to secondary wastewater treatment is $20 \mathrm{mg} \mathrm{L}^{-1}$ (Yaseen and Scholz 2018). All outflow values were lower than this limit.

Concerning $\mathrm{NO}_{3}-\mathrm{N}$, all mean outflow concentrations (Supplementary material 5) were lower compared to the inflow ones (Supplementary material 4). In terms of removal efficiency, ponds containing dye exhibited low $\mathrm{NO}_{3}-\mathrm{N}$ removal, which ranged between 16 and $47 \%$. In addition, all $\mathrm{NO}_{3}$-N removal values (Fig. 4d) were significantly higher ( $t$ test, $p<0.05$ ) in planted ponds than in unplanted ones, except for ponds treating BR46 at low and high $\mathrm{pH}$ values. These findings suggest that the plants acquire nitrate as a second source after ammonia has been taken up. This results in a significant potential for $\mathrm{NO}_{3}-\mathrm{N}$ reduction by plants in addition to the denitrification mechanism. However, ponds treating BR46 at acidic conditions provide unexpected results of higher removal in control ponds than in the planted ponds, which indicates that denitrification was the main mechanism for $\mathrm{NO}_{3}-\mathrm{N}$ removal and the plant contribution was marginal. This may attribute to plant detritus, which plays an important role in nutrient recycling within the system (Zhang et al. 2014). The UK Government (1994) has set no threshold for $\mathrm{NO}_{3}-\mathrm{N}$. Nonetheless, the traditional limit for secondary wastewater is $50 \mathrm{mg} \mathrm{L}^{-1}$ as discussed by Yaseen and Scholz (2018). All outflow values were less than this limit. It is important to mention that anaerobic microniches within the pond system also have a small contribution 
to the increase in the denitrification rate. In addition, around $4 \%$ of the initial nitrogen was reduced by nitrification and denitrification. This can be explained by the micro-sites of the bio-film attached to L. minor.

Ortho-phosphate-phosphorus $\left(\mathrm{PO}_{4}-\mathrm{P}\right)$ mean outflow concentrations (Supplementary material 5) were elevated compared to the inflow recordings (Supplementary material 4) with respect to all dyes indicating low $\mathrm{PO}_{4}-\mathrm{P}$ reduction. Mean outflow values for planted wetlands were significantly lower $(t$ test, $p<0.05$ ) than the respective values for the unplanted ones concerning all dyes. This reflects the $\mathrm{PO}_{4}$-P removal efficiencies (Fig. 4e), which were significantly $(p<0.05)$ higher with respect to planted ponds compared to the unplanted ones excluding the ponds comprising RB198 at low and high $\mathrm{pH}$, which were not significant $(p>0.05)$. These findings indicate that plants contributed to the removal of $\mathrm{PO}_{4}-\mathrm{P}$ and that the mechanism of phosphorus removal in planted ponds was attributed to the uptake and assimilation of phosphorus into L. minor protein, adsorption on the fronds of the plant, chemical precipitation and uptake by micro-organisms. However, only the uptake by microbes and biological processes are responsible for $\mathrm{PO}_{4}$-P reduction in unplanted ponds.

The UK Government (1994) did not set a limit for $\mathrm{PO}_{4}-\mathrm{P}$ that relates to the treatment system in this study. However, a realistic guideline threshold could be $1 \mathrm{mg} \mathrm{L}^{-1}$ (Yaseen and Scholz 2018). However, most outflow values were then non-compliant. Regarding the impact of $\mathrm{pH}$ inflow values, $\mathrm{PO}_{4}-\mathrm{P}$ removal by unplanted ponds treating BR46 at high $\mathrm{pH}$ was significantly (Kruskal-Wallis, $p<0.05$ ) higher than those at normal and low $\mathrm{pH}$.

Mean outflow values of parameters including colour, $\mathrm{pH}$, redox potential, DO, SS, turbidity, EC and TDS are shown in Supplementary material 5. A discussion of these parameters are presented in Supplementary material 3b.

\section{Outflow Water Quality Parameters (Phase 2)}

Supplementary material 6 summarises the overall outflow water quality parameters for each system concerning the second experiment (second phase) between 18 October 2016 and 30 June 2017. Figure 6 shows the mean removal efficiency of the dyes, COD and nutrients for each system related to the second phase of the second experiment that ran between 18 October 2016 and 30 June 2017. Figure 7 highlights the UV-Vis analysis for the inflow and outflow samples for each dye linked with the second phase of the second experiment.

The pond systems exhibited no removal efficiencies for the dye RB198, and the differences between the design parameters were low (Fig. 6a). In addition, the mean outflow concentrations (Supplementary material 6) were higher compared to those of the inflow (Supplementary material
4) and showed no significant differences (Kruskal-Wallis, $p=0.548$ ) among the design variables. These results indicated that the presence or absence of algae in the system does not affect the pond performance in terms of RB198 treatment. The highest and lowest removals were 6 and $-26 \%$ for L. minor and algae ponds, respectively, and 13 and $-30 \%$ for algae ponds in that order, and $11 \%$ and $-23 \%$ for control ponds, respectively. The negative removal numbers suggested that the system works as a source rather than a sink, which could be due to surface evaporation phenomena or dried dye sticking on the wall of the pond sides after weekly doses (Yaseen and Scholz 2016).

The dye BR46 was removed significantly higher than RB198 due to the absence of sulphonic groups, low molecular weight and the simple structure of BR46, making this dye easy-to-absorb and degradable (Yaseen and Scholz 2017 a, b). The mean removal of BR46 was highest for $L$. minor and algae ponds (89\%) followed by only algae ponds (58\%), and the lowest removal (33\%) is linked to unplanted ponds. These results reflected the mean outflow BR46 (Supplementary material 6) concentrations, which were as follows: $L$. minor and algae ponds $\left(0.5 \mathrm{mg} \mathrm{L}^{-1}\right)<$ algae ponds $\left(2.4 \mathrm{mg} \mathrm{L}^{-1}\right)<$ control ponds $\left(5 \mathrm{mg} \mathrm{L}^{-1}\right)$. All dissimilarities between the design parameters in terms of the outflow concentrations and the removal values were statistically significant (Kruskal-Wallis, $p=0.000$ ). These findings suggest that the influence of $L$. minor and algae on BR46 elimination is 31 and $25 \%$ in this order. These findings match with those of Yaseen and Scholz (2016), although the potential of $L$. minor was a slightly lower in this study, which may be due to the impact of increasing the concentration to $10 \mathrm{mg} \mathrm{L}^{-1}$ in this study compared with only $5 \mathrm{mg} \mathrm{L}^{-1}$.

The main peak for the RB 198 colour at $625 \mathrm{~nm}$ showed a clear increase in outflow samples related to L. minor and algae, algae and control ponds (Fig. 7a). This indicates that the outflow concentrations increased. However, the dye BR46 (Fig. 7b) showed a complete disappearance of the colour peak at $530 \mathrm{~nm}$ for ponds planted with $L$. minor and algae confirming complete decolourisation. In addition, algae ponds showed considerable elimination of the peak at $530 \mathrm{~nm}$ confirming the high reduction in outflow concentrations, although the outflow samples were not fully colourless. However, control ponds showed some reduction in the peak at $530 \mathrm{~nm}$ indicating a decrease in the outflow concentration due to microbial bio-sorption processes.

The HPLC chromatogram analysis (data not shown) showed that the RB198 inflow peak at a retention time of $1.505 \mathrm{~min}$ shifted to $1.633,1.793$ and $1.523 \mathrm{~min}$ in ponds planted with $L$. minor and algae, algae only and controls, respectively. These bands in planted ponds could considerably shift in contrast to the control ponds due to interactions between plants, algae and the wastewater. However, for the dye BR46, the inflow peak at $1.488 \mathrm{~min}$ shifted to $1.485 \mathrm{~min}$ 
Fig. 6 Mean removal efficiencies during the experimental period between 18 October 2016 and 30 June 2017: a dyes; b chemical oxygen demand; c ammonium-nitrogen; $\mathbf{d}$ nitrate-nitrogen; and e orthophosphate-phosphorous. AWW, artificial wastewater; TW, tap water; LA, ponds planted with L. minor and algae; A, ponds planted with algae; $\mathrm{C}$, unplanted ponds
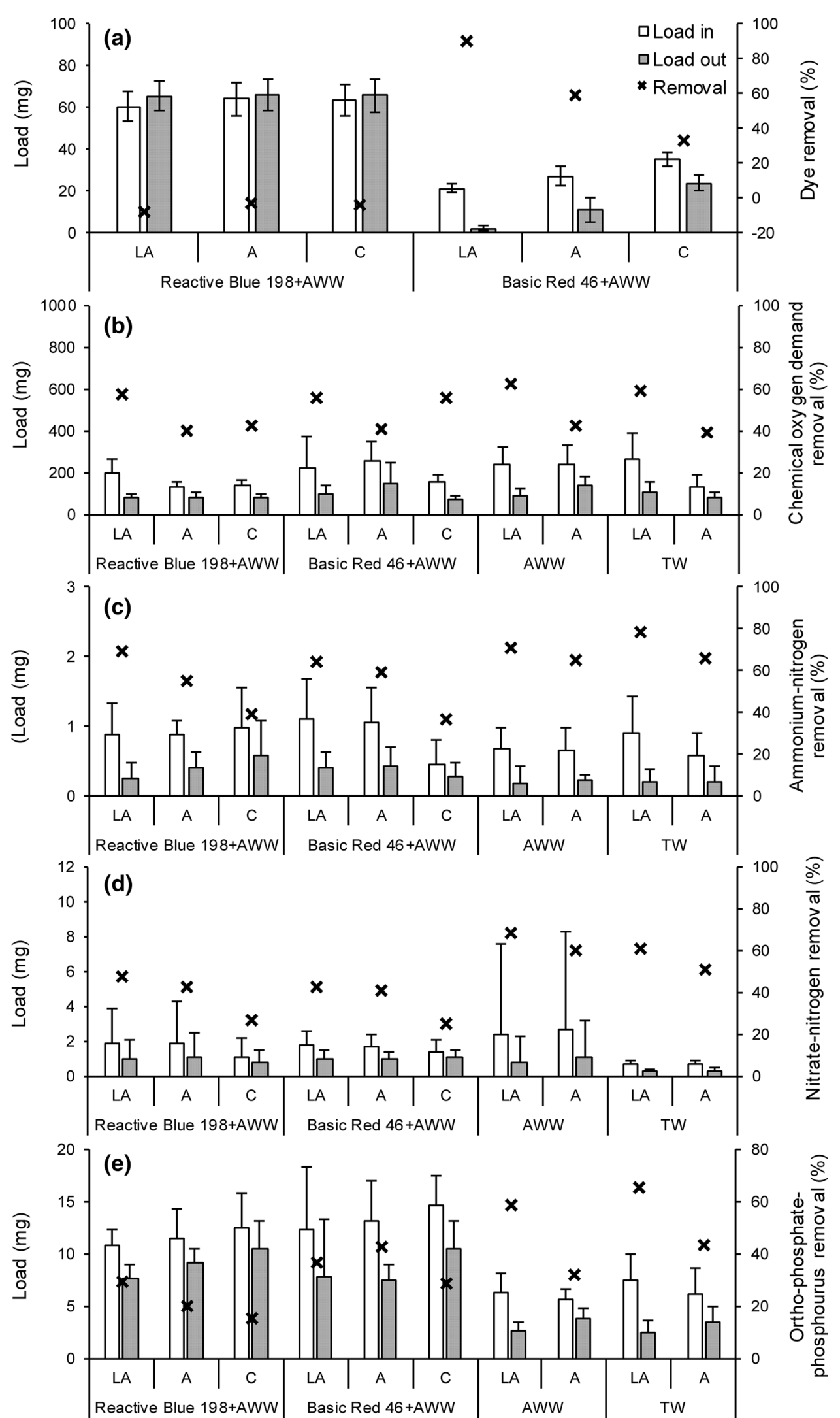

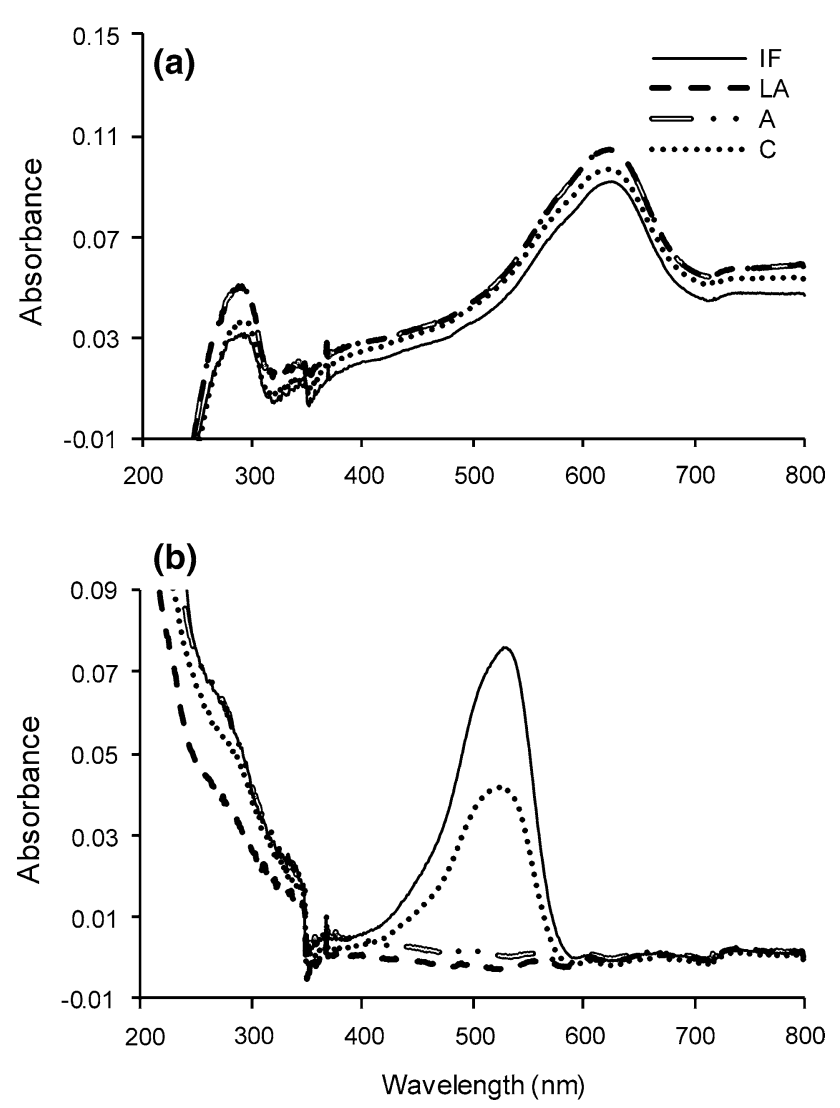

Fig. 7 Ultraviolet visible analysis for the outflow samples at the end of second experiment (second phase): a Reactive Blue 198 and b Basic Red 46. IF, inflow; LA, outflow of ponds planted with $L$. minor and algae; A, outflow of ponds planted with algae; $C$, unplanted ponds

with the appearance of a new peak at 2.779 min for the $L$. minor and algae ponds, and the inflow peak at 1.488 shifted to 1.52 min with the appearance of a new peak at $2.276 \mathrm{~min}$ for the algae ponds. In addition, all other inflow peaks disappeared, confirming dye degradation due to phyto-transformation and bio-transformation processes as mentioned previously in "Outflow Water Quality Parameters (Phase 1)" section. However, the control ponds showed appearances of new peaks at $2.796 \mathrm{~min}$ and the band at 2.405 shifted to 2.2, and the elimination of other inflow peaks was observed. As mentioned by Somasiri et al. (2006), the cleavage of azo bonds due to dye degradation produced toxic intermediates called aromatic amines, and due to the short life of these intermediates, it was difficult to identify these products by HPLC analysis. Therefore, gas chromatography-mass spectrometry (GCMS) analysis was used for aromatic amine identification.

The GCMS results (provided by Concept Life Sciences Analytical and Development Services Limited) for the outflow of L. minor and algae ponds treating RB198 showed that there were no aromatic amines. This was because the breakage of azo bonds as a first step for the treatment did not occur and, consequently, no intermediates (aromatic amine) were produced. This result could be generalised for the algae and control ponds due to the same removal processes expected for all ponds treating RB198.

Concerning the dye BR46 treated by L. minor and algae ponds, no aromatic amines were detected in the residual dye bath. This finding indicates that the cleavage product is completely mineralised. However, the outflow samples of algae ponds containing BR46 showed the presence of three aromatics: benzenemethanamine, $N$-methyl (CAS number 103-67-3), benzenamine, 4-methoxy- $N$-methyl (CAS number 5961-59-1), and 1-triazene, 1-(4-methylphenyl)-3(phenylmethyl) (CAS number 17683-09-9). The concentrations were lower than $10 \mathrm{mg} \mathrm{L}^{-1}$, which is the detection limit of the equipment. This suggests that although algae were able to remove a considerable amount of colour, they are incapable of completely mineralising the dye within the systems.

In this study, bio-transformation to colourless intermediates (aromatic amines) and bio-sorption processes are likely to be responsible for colour removal by algae. Holkar et al. (2016) mentioned that the main mechanisms for dye removal by algae are bio-sorption (the dye moves from the water phase to the solid phase) and bio-transformation. (Algae break down the azo dye to colourless intermediates or carbon dioxide and water.)

According to the Regulation (EC) No. 1907/2006, the first aromatic (CAS number 103-67-3) can cause severe skin burns, eye damage, allergic skin reaction, asthma symptoms and breathing difficulties, if inhaled. Therefore, environmental agencies often prevent this product from entering drains. However, the second amine (CAS number 5961-59-1) has been confirmed as a non-hazardous substance according to the Regulation (EC) No. 1272/2008. In addition, it does not contain components considered to be persistent, bioaccumulative and toxic (PBT), very persistent and very bioaccumulative (vPvB) at levels of $0.1 \%$ or higher. Therefore, no special environmental exposure precautions are required. Furthermore, no component of these two aromatics present at levels greater than or equal to $0.1 \%$ has been identified as a probable, possible or confirmed human carcinogen, whereas there are no data available for the third aromatic (CAS number 17683-09-9). However, as an environmental precaution, it has been recommended not to allow this aromatic material to enter drains or watercourses.

Regarding the sample collected from the control ponds containing BR46, the analysis detected two peaks of concentrations below $10 \mathrm{mg} \mathrm{L}^{-1}$. One peak was identified as $N$-(4-methylphenyl)-benzenemethanamine (CAS number 5405-15-2) and the other one was unidentifiable, but the closest match had an aromatic amine structure. This confirms that the pond system without L. minor was unable to 
mineralise the dye BR46. $N$-(4-methylphenyl)-benzenemethanamine is considered as a non-hazardous substance. However, for environmental precautions the discharge of this compound must be avoided.

Sponza and Isik (2005) conducted different toxicity tests after each stage of Direct Red 28 treatment. They concluded that the outflow samples of the first stage in dye removal (decolourisation step) are toxic to plants and animals. However, continued degradation completed mineralisation, decreased the toxicity of the parent compound and eliminated the toxic impact on micro-organisms. Therefore, in this study, the toxic impacts of the outflow samples in $L$. minor ponds, which completely mineralised the dye, were expected to be eliminated, whereas within the algae and control ponds, toxic effects are associated with the effluents depending on the toxicity of the aromatics.

The removal efficiency of COD during the experimental period showed no significant differences $(p>0.05)$ among the design variables in ponds containing dyes. However, for ponds without dyes, the values were significantly higher (Mann-Whitney $U, p<0.05$ ) in the combined L. minor and algae ponds than in the corresponding algae-only ponds (Fig. 6b). In addition, no significant differences $(p>0.05)$ were found between the design parameters in terms of average outflow COD concentrations (Supplementary material 6) for both dyes, which were lower compared to the inflow ones (Supplementary material 4). All these findings indicated that the presence of dyes in the system has an adverse effect on organic matter degradation, which can be attributed to the dye impact on the plants. However, algae do not seem to be affected by the dye due to the COD removal similarity in all algae ponds with and without dye. This indicates that the COD degradation was due to microbial activities for all systems except $L$. minor and algae ponds without dyes. In this phase, all outflow COD values were less than the standard limits.

Regarding $\mathrm{NH}_{4}-\mathrm{N}$, higher removal was found in ponds planted with $L$. minor and algae followed by algae ponds and the lowest removal was noticed in control ponds for all treatment systems (Fig. 6c). Significant differences (oneway ANOVA, $p<0.05$ ) were found between ponds planted with $L$. minor and algae, and control ponds for both dyes. In terms of outflow concentrations, the values were lower compared to the corresponding inflow concentrations (Supplementary materials 6 and 4, respectively), although the outflow numbers were higher in the control ponds than in the planted ponds. These results showed that both L. minor and algae contributed to nitrogen removal. However, the removal values for algae ponds compared with $L$. minor and algae ponds for all treatment systems (Fig. 6c) suggested that algae have higher contributions to nitrogen removal than L. minor. This result confirmed findings previously reported by Kadlec et al. (2000) that the plant potential does not exceed $10 \%$ of the total nitrogen removal. In addition, this also attributes to the impact of mean $\mathrm{pH}$ outflows, which were higher than 7 in this study. He mentioned that higher nitrogen removal occurs in algae ponds than L. minor ponds in case of $\mathrm{pH}$ values between 7 and 9 as a best condition for algae growth. Nitrogen removal is due to biological uptake by dispersed algae, which settle and attach themselves to the wall of the ponds. However, L. minor is able to accumulate nitrogen. The other impact for $\mathrm{NH}_{4}-\mathrm{N}$ removal in this study was the nitrification process by nitrifying bacteria as explained previously. The results shown in Fig. $6 \mathrm{c}$ confirm the outcome of the first phase highlighting that the presence of the dye impacted the $\mathrm{NH}_{4}-\mathrm{N}$ removal efficiency. All the outflow values of $\mathrm{NH}_{4}-\mathrm{N}$ in this phase were lower than the threshold limit.

Based on $\mathrm{NO}_{3}-\mathrm{N}$, a low mean removal efficiency was found in all ponds, especially the control ones (Fig. 6d). The removal values follow this order: $L$. minor and algae ponds $>$ algae ponds $>$ control ponds. Statistically significant $(p<0.05)$ differences were found between ponds planted with $L$. minor and algae, ponds planted with algae only compared to the control wetlands. In terms of $\mathrm{NO}_{3}-\mathrm{N}$ concentrations, all average outflow concentrations were lower compared to the inflow ones (Supplementary materials 6 and 4 , respectively), although the control ponds showed outflow concentrations higher than the planted ponds.

These findings indicated that L. minor and algae used nitrate as a source for nutrients resulting in a significant $(p<0.05)$ potential for $\mathrm{NO}_{3}-\mathrm{N}$ reduction by both $L$. minor and algae, in addition to the denitrification mechanism. However, it seems that the potential of algae is higher than that of L. minor due to the same removal found in algae ponds compared with ponds containing both algae and $L$. minor. This is because algae reduced at the presence of $L$. minor due to shading making the impact of both of them together similar to ponds containing algae or L. minor separately. Note that in this phase, anaerobic micro-niches within the container also have some contribution to the denitrification rate, in addition to the impact of micro-sites of the bio-film attached to L. minor, supporting both nitrification and denitrification.

The $\mathrm{PO}_{4}-\mathrm{P}$ removal efficiency was very low for all ponds containing dyes compared with ponds without dyes (Fig. 6e). In addition, the removal of ponds planted with $L$. minor and algae was significantly higher than that of algae ponds containing RB198, control wetland systems comprising RB198, and algae wetlands without dyes. It was evident that the state of $L$. minor was better in these ponds due to the potential of $L$. minor for phosphorus uptake compared with systems treating BR46. Results of low removal reflect the high outflow values, which were higher than the inflow values for all ponds containing dyes (Supplementary materials 6 and 4, respectively). These findings indicate that the mechanisms of phosphorus removal were the uptake by plants and 
microbes, which are the main mechanisms for phosphorus removal in wetlands (Vymazal 2007). Generally, these low removal efficiencies were expected due to the relatively low potential of wetland systems for $\mathrm{PO}_{4}-\mathrm{P}$ removal. The UK Government (1994) does not set regulations for $\mathrm{PO}_{4}-\mathrm{P}$ relating to the treatment system in this study. All outflow values concerning $L$. minor and algae, algae, and control ponds containing RB198 as well as algae and control ponds treating BR46 were non-compliant. However, L. minor and algae ponds comprising BR46, algae ponds containing artificial wastewater, L. minor and algae, and algae ponds containing tap water were 3,1, 1 and 1 times non-compliant concerning the guideline threshold for $\mathrm{PO}_{4}-\mathrm{P}$, which is $1 \mathrm{mg} \mathrm{L}^{-1}$ (Yaseen and Scholz 2018).

For both phases, the artificial wastewater composition supplied energy to micro-organisms to enhance denitrification by providing a long-term source of carbon and nutrients, which supported the micro-organism population as well. This source of carbon is necessary as during the nitrification process carbon dioxide is utilised as a source of carbon and energy. The denitrification process under anoxic conditions requires carbon, which is lacking at the end of nitrification process. High nitrate concentrations present in the system outflow indicate limited denitrification, which is due to the fact that most carbon sources have been utilised by the nitrification process. In terms of dye removal efficiency, the carbon source in the artificial wastewater boosted the colour reduction and dye metabolism. Therefore, the carbon source promoted the long-term functioning of wetlands.

Mean outflow values of water quality parameters including colour, $\mathrm{pH}$, redox potential, DO, SS, turbidity, EC and TDS are shown in Supplementary material 6. A corresponding discussion of both these parameters is shown in Supplementary material $3 \mathrm{c}$.

\section{Environmental Conditions}

The mean temperature was $25^{\circ} \mathrm{C}$ and $23^{\circ} \mathrm{C}$ for the first and second phases, respectively. The maximum and minimum values were $29^{\circ} \mathrm{C}$ and $21^{\circ} \mathrm{C}$ for the first phase, and $27^{\circ} \mathrm{C}$ and $19{ }^{\circ} \mathrm{C}$ for the second phase in this order. Ozengin and
Elmaci (2007) mentioned that the optimum temperature for optimum growth of $L$. minor is $26^{\circ} \mathrm{C}$ and the growth of L. minor reduced at temperature values below $17^{\circ} \mathrm{C}$ and higher than $35^{\circ} \mathrm{C}$. Therefore, temperature records in this experiment did not affect the growth of plants in the system. Regarding light intensity, Yin et al. (2015) found that plant production increased with an increase in the light intensity between $1480 \mathrm{~lx}$ and $8140 \mathrm{~lx}$. The mean readings of light intensity were $6962 \mathrm{~lx}$ and $6853 \mathrm{~lx}$ for the first and second phases, respectively, which were within this range. Table 2 provides an overview of laboratory conditions during the experimental study.

\section{Plant Monitoring}

The overall average values of the relative growth rate during the experimental period based on the fresh weights are shown in Table 3. This growth factor has been used as a pointer for the toxicity of dyes and the artificial wastewater on $L$. minor growth. For the first phase between 20 January 2016 and 18 October 2017, results showed that the mean values of plant growth rate were higher in ponds comprising only tap water followed by wetlands treating artificial wastewater. The ponds comprising synthetic wastewater mixed with RB198 were linked to a significantly (oneway ANOVA, $p<0.05$ ) higher growth compared to ponds containing artificial wastewater mixed with BR46. These outcomes suggest that the artificial wastewater used in this study reduced the growth of the plants but not the toxic level as in the first experiment. In addition, the presence of dyes negatively impacts the growth rate, which is especially the case for BR46, which has been successfully treated. The same findings were observed for BR46 at a concentration of $5 \mathrm{mg} \mathrm{L}^{-1}$ inhibiting $L$. minor growth (Yaseen and Scholz 2016). The impact of $\mathrm{pH}$ on the plant development was not significant for both dyes, although the growth values were slightly higher in ponds receiving inflow of a $\mathrm{pH}$ value of 6 followed by the values at normal conditions. A lower growth rate was linked to ponds receiving inflow of a $\mathrm{pH}$ value of 9 for both studied dyes. This can be explained by the mean outflow $\mathrm{pH}$ values (Supplementary material 5). The findings
Table 3 Relative growth rate (RGR) of L. minor L. during the experimental period

\begin{tabular}{|c|c|c|c|c|}
\hline \multirow[t]{2}{*}{ Treatment system } & \multicolumn{3}{|c|}{$\begin{array}{l}\text { RGR (per day) for the period } \\
\text { between } 20 \text { January } 2016 \text { and } 18 \\
\text { October } 2017\end{array}$} & \multirow{2}{*}{$\begin{array}{l}\text { RGR (per day) for the period between } \\
20 \text { January } 2016 \text { and } 30 \text { June } 2017 \\
\text { pH } 7\end{array}$} \\
\hline & pH 6 & pH 7 & pH 9 & \\
\hline Reactive Blue $198+$ AWW & 0.01380 & 0.01378 & 0.01371 & 0.00713 \\
\hline Basic Red 46+AWW & 0.01174 & 0.01161 & 0.01137 & 0.00561 \\
\hline AWW & N/A & 0.01414 & N/A & 0.00703 \\
\hline TW & N/A & 0.01492 & N/A & 0.00733 \\
\hline
\end{tabular}

$R G R$ relative growth rate, $A W W$ artificial wastewater, $T W$ tap water, $N / A$ not applicable 
matched those by Movafeghi et al. (2013) and Khataee et al. (2012) indicating that the optimum growth conditions for $L$. minor were at $\mathrm{pH}$ values between 6 and 7.5.

At the end of the second phase, the overall growth rate was calculated according to the experimental period between 20 January 2016 and 30 June 2017. The growth values were significantly lower than the growth rate within the first period. This could be attributed to the weekly doses accumulated in the system during this long period making the plant exhausted and over-saturated with nutrients. Especially in the second phase, the plants were not harvested monthly, because they suffered and did not spread over the surface area. The relative growth rates of the ponds containing tap water were higher than for the other ponds followed by ponds containing RB198 and ponds containing only artificial wastewater, which were not significantly $(p>0.05)$ different from each other. Visual monitoring of the plants at the end of the experiment with the help of the Munsell Color (1977) chart showed that L. minor in ponds containing tap water was associated with light green $(2.5 \mathrm{GY})$ and dark green $(5 \mathrm{GY})$ fronds. In comparison, ponds comprising artificial wastewater only and RB198 mixed with artificial wastewater showed that most of the fronds were linked to dark green $(5 \mathrm{GY})$. This can be ascribed to the lack of nutrients in ponds receiving only tap water, although a lack of nutrients did not affect the growth of L. minor. The photosynthetic process and the chlorophyll content are not affected considerably (Khataee et al. 2012) as the fronds remained green in colour with some variation of the degree of this colour among the ponds. Furthermore, the presence of white fronds in all ponds with and without dyes indicated the dieoff of $L$. minor during its life cycle.

Finally, a significantly $(p<0.05)$ lower growth was observed in ponds comprising BR46. Note that almost all plants in these ponds died, decomposed and turned brown. Only a low percentage of plants were associated with light green (2.5 GY), dark yellow (5 Y) and white colour. This may be due to the impact of aromatic amines.

\section{Conclusions and Recommendations}

This study concluded that the pond system effectively removed the dye BR46 at a concentration of $10 \mathrm{mg} \mathrm{L}^{-1}$ compared with the dyes AB113, RB198 and DO46. No significant impacts of different $\mathrm{pH}$ values regarding the treatment performance were noted. Furthermore, the removal of BR46 within ponds planted with $L$. minor and algae or only algae by phyto-transformation, bio-transformation and adsorption process was significantly $(p<0.05)$ higher than the corresponding removal by the control ponds, which was due to bio-transformation and bio-sorption processes. In addition, this study highlights the potential of $L$. minor ponds for complete mineralisation of BR46 by removing the aromatic amines after dye decolourisation compared with algae and control ponds, which consequently shows the effectiveness of $L$. minor. The potential of $L$. minor and algae for elimination of BR46 colour was around $31 \%$ and $25 \%$, respectively. All outflow COD, $\mathrm{NH}_{4}-\mathrm{N}, \mathrm{NO}_{3}-\mathrm{N}, \mathrm{SS}$ and TDS concentrations were below the standard discharge thresholds. Therefore, the treated effluents were suitable for safe discharge or reusable for other purposes.

Artificial wastewater used at $100 \%$ was not suitable with $L$. minor treatment systems. Dilution of the artificial wastewater (1 part of artificial wastewater to 24 parts of raw water) was required for the treatment systems using $L$. minor, although the growth was inhibited. Dyes reduced the growth rate of $L$. minor. This was particularly the case for BR46.

Overall, this work suggests that wetland systems planted with $L$. minor are successful and economic in the complete degradation of the dye BR 46 at concentrations of $10 \mathrm{mg} \mathrm{L}^{-1}$ with any $\mathrm{pH}$ value between 6 and 9 . However, a lower dye concentration is preferable to keep the plants alive for longterm treatments. This approach could help low-income developing countries suffering from textile effluents by treating and consequently recycling of these effluents. Further research on assessing the potential of pond systems for removing other azo dyes is required.

\section{Supplementary Material}

This article is supported by supplementary information that is linked to the article version published online. Supplementary Materials 1-6 provide information about the inflow water quality of the first experiment, outflow water quality of the first experiment, discussion of some water quality parameters of both experiments, inflow water quality of the second experiment, outflow water quality of the second experiment (first and second phases), respectively.

Acknowledgements The lead author received a $\mathrm{Ph} . \mathrm{D}$. scholarship financially supported by the Ministry of Higher Education and Scientific Research of the Government of Iraq. The sponsor had no influence over the content of this project.

\section{Compliance with Ethical Standards}

Conflict of interest The authors have declared no conflict of interest.

Open Access This article is distributed under the terms of the Creative Commons Attribution 4.0 International License (http://creativeco mmons.org/licenses/by/4.0/), which permits unrestricted use, distribution, and reproduction in any medium, provided you give appropriate credit to the original author(s) and the source, provide a link to the Creative Commons license, and indicate if changes were made. 


\section{References}

APHA (2005) Standard methods for the examination of water and wastewater, 21st edn. American Public Health Association (APHA), American Water Works Association, and Water and Environment Federation, Washington DC

Chandanshive VV, Rane NR, Gholave AR, Patil SM, Jeon B, Govindwar SP (2016) Efficient decolorization and detoxification of textile industry effluent by Salvinia molesta in lagoon treatment. Environ Res 150:88-96

Chandran D (2016) A review of the textile industries waste water treatment methodologies. Int J Sci Eng Res 7:392-403

Dalu J, Ndamba J (2003) Duckweed based wastewater stabilization ponds for wastewater treatment (a low cost technology for small urban areas in Zimbabwe). Phys Chem Earth 28:1147-1160

Ghaly A, Ananthashankar R, Alhattab M, Ramakrishnan V (2014) Production, characterization and treatment of textile effluents: a critical review. Chem Eng Proc Technol 5:1-18

Holkar CR, Jadhav AJ, Pinjari DV, Mahamuni NM, Pandit AB (2016) A critical review on textile wastewater treatments: possible approaches. J Environ Manag 182:351-366

Kabra AN, Khandare RV, Waghmode TR, Govindwar SP (2012) Phytoremediation of textile effluent and mixture of structurally different dyes by Glandularia pulchella (Sweet) Tronc. Chemosphere $87: 265-272$

Kadlec RH, Knight RL, Vymazal J, Brix H, Cooper P, Haberl R (2000) Constructed Wetlands for Pollution Control: process, performance, design and operation. International Water Association, London

Kagalkar AN (2011) Phytoremediation: a novel approach for degradation of textile dyes. PhD thesis. Shivaji University, Shivaji

Khandare RV, Kabra AN, Tamboli DP, Govindwar SP (2011) The role of Aster amellus Linn. in the degradation of a sulfonated azo dye Remazol Red: a phytoremediation strategy. Chemosphere 82:1147-1154

Khataee A, Movafeghi A, Torbati S, Lisar SS, Zarei M (2012) Phytoremediation potential of duckweed (Lemna minor L.) in degradation of c. i. acid blue 92: artificial neural network modeling. Ecotoxicol Environ Saf 80:291-298

Movafeghi A, Khataee A, Torbati S, Zarei M, Lisar S (2013) Bioremoval of C. I. basic red 46 as an azo dye from contaminated eater by Lemna minor L.: modeling of key factor by neural network. Environ Progr Sustain Energy 32:1082-1089

Munsell A (1977) Munsell color charts for plant tissues, 2nd edn. Macbeth, Kollmorgen Corporation, Baltimore

Ong SA, Uchiyama K, Inadama D, Yamagiwa K (2009) Simultaneous removal of color, organic compounds and nutrients in azo dye-containing waste water using up-flow constructed wetland. J Hazard Mater 165:696-703

Ong SA, Uchiyama K, Inadama D, Ishida Y, Yamagiwa K (2010) Treatment of azo dye acid orange 7 containing wastewater using up-flow constructed wetland with and without supplementary aeration. Bioresour Technol 101:9049-9057

Ozengin N, Elmaci A (2007) Performance of Duckweed (Lemna minor L.) on different types of wastewater treatment. J Environ Biol 28:307-314

Pearce C, Lloyd J, Guthrie J (2003) The removal of colour from textile wastewater using whole bacterial cells: a review. Dyes Pigments 58:179-196

Reema R, Saravanan P, Kumar MD, Renganathan S (2011) Accumulation ofmethylene blue dye by growing Lemna minor. Sep Sci Technol 46:1052-1058

Salleh MAM, Mahmoud DK, Abdul Karim WAW, Idris A (2011) A cationic and anionic dye adsorption by agricultural solid wastes: a comprehensive review. Desalination 280:1-13

Saratale RG, Saratale G, Chang J, Govindwar S (2011) Bacterial decolorization and degradation of azo dyes: a review. J Taiwan Inst Chem Eng. 42:138-157

Somasiri W, Ruan W, Xiufen L, Jian C (2006) Decolorization of textile wastewater containing acid dyes in UASB reactor system under mixed anaerobic granular sludge. Electron J Environ Agric Food Chem 5:1224-1234

Sponza DT, Isik M (2005) Toxicity and intermediates of C.I. Direct Red 28 dye through sequential anaerobic/aerobic treatment. Proc Biochem 40:2735-2744

Tahir U, Yasmin A, Khan UH (2016) Phytoremediation: potential flora for synthetic dyestuff metabolism. J King Saud Univ Sci 28:119-130

UK Government (1994) Urban waste water treatment (England and Wales) regulations 1994 (SI 1994 No. 2841). Government of the United Kingdom, London

Vymazal J (2007) Removal of nutrients in various types of constructed wetlands. Sci Total Environ 380:48-65

Yaseen D, Scholz M (2016) Shallow pond systems planted with Lemna minor treating azo dyes. Ecol Eng 94:295-305

Yaseen D, Scholz M (2017a) Comparison of experimental ponds for the treatment of dye wastewater under controlled and semi-natural conditions. Environ Sci Pollut Res 24:16031-16040

Yaseen D, Scholz M (2017b) Textile dye removal using experimental wetland ponds planted with common duckweed under semi-natural conditions. Environ Prot Eng 43:39-60

Yaseen D, Scholz M (2018) Treatment of synthetic textile wastewater containing dye mixtures with microcosms. Environ Sci Pollut Res 25:1980-1997

Yin Y, Yu C, Yu L, Zhao J, Sun G, Ma Y, Zhou G (2015) The influence of light intensity and photoperiod on duckweed biomass and starch accumulation for bioethanol production. Biores Technol 187:84-90

Zhang X, Song C, Mao R, Yang G, Tao B, Shi F et al (2014) Litter mass loss and nutrient dynamics of four emergent macrophytes during aerial decomposition in freshwater marshes of the Sanjiang plain, Northeast China. Plant Soil 385:139-147 